\title{
Climate, people, fire and vegetation: new insights into vegetation dynamics in the Eastern Mediterranean since the 1st century AD
}

\author{
J. Bakker ${ }^{1,2}$, E. Paulissen ${ }^{1}$, D. Kaniewski ${ }^{2,3}$, J. Poblome ${ }^{4}$, V. De Laet $^{1,2}$, G. Verstraeten ${ }^{1,2}$, and M. Waelkens ${ }^{4}$ \\ ${ }^{1}$ Department of Earth and Environmental Sciences, University of Leuven, Celestijnenlaan 200E, P.O. Box 2409, \\ 3001 Heverlee, Belgium \\ ${ }^{2}$ Center for Archaeological Sciences, University of Leuven, Celestijnenlaan 200E, P.O. Box 2408, 3001 Heverlee, Belgium \\ ${ }^{3}$ Université de Toulouse, UPS, INPT, EcoLab (Laboratoire d'Ecologie Fonctionnelle), 29 rue Jeanne Marvig, \\ 31055 Toulouse, France \\ ${ }^{4}$ Sagalassos Archaeological Research Project, University of Leuven, Blijde Inkomststraat 21, P.O. Box 3314, \\ 3000 Leuven, Belgium
}

Correspondence to: J. Bakker (johan.bakker@ees.kuleuven.be)

Received: 10 July 2012 - Published in Clim. Past Discuss.: 13 August 2012

Revised: 3 December 2012 - Accepted: 11 December 2012 - Published: 16 January 2013

\begin{abstract}
Anatolia forms a bridge between Europe, Africa and Asia and is influenced by all three continents in terms of climate, vegetation and human civilisation. Unfortunately, well-dated palynological records focussing on the period from the end of the classical Roman period until subrecent times are rare for Anatolia and completely absent for southwest Turkey, resulting in a lacuna in knowledge concerning the interactions of climatic change, human impact, and environmental change in this important region. Two well-dated palaeoecological records from the Western Taurus Mountains, Turkey, provide a first relatively detailed record of vegetation dynamics from late Roman times until the present in SW Turkey. Combining pollen, non-pollen palynomorphs, charcoal, sedimentological, archaeological data, and newly developed multivariate numerical analyses allows for the disentangling of climatic and anthropogenic influences on vegetation change. Results show changes in both the regional pollen signal as well as local soil sediment characteristics match shifts in regional climatic conditions. Both climatic as well as anthropogenic change had a strong influence on vegetation dynamics and land use. A moist environmental trend during the late-3rd century caused an increase in marshes and wetlands in the moister valley floors, limiting possibilities for intensive crop cultivation at such locations. A mid-7th century shift to pastoralism coincided with a climatic deterioration as well as the start of Arab incursions into the region, the former driving the way in which the vegetation developed afterwards. Resurgence in agriculture was observed in
\end{abstract}

the study during the mid-10th century $\mathrm{AD}$, coinciding with the Medieval Climate Anomaly. An abrupt mid-12th century decrease in agriculture is linked to socio-political change, rather than the onset of the Little Ice Age. Similarly, gradual deforestation occurring from the 16th century onwards has been linked to changes in land use during Ottoman times. The pollen data reveal that a fast rise in Pinus pollen after the end of the Beyşehir Occupation Phase need not always occur. The notion of high Pinus pollen percentages indicating an open landscape incapable of countering the influx of pine pollen is also deemed unrealistic. While multiple fires occurred in the region through time, extended fire periods, as had occurred during the Bronze Age and Beyşehir Occupation Phase, did not occur, and no signs of local fire activity were observed. Fires were never a major influence on vegetation dynamics. While no complete overview of post-BO Phase fire events can be presented, the available data indicates that fires in the vicinity of Gravgaz may have been linked to anthropogenic activity in the wider surroundings of the marsh. Fires in the vicinity of Bereket appeared to be linked to increased abundance of pine forests. There was no link with specifically wet or dry environmental conditions at either site. While this study reveals much new information concerning the impact of climate change and human occupation on the environment, more studies from SW Turkey are required in order to properly quantify the range of the observed phenomena and the magnitude of their impacts. 


\section{Introduction}

Anatolia is characterized by a complex history of climate and human-related vegetation change, presenting a challenge to palaeoecological researchers who work in this region (Bottema and Woldring, 1990; Kaniewski, 2007a; Riehl and Marinova, 2008). The region forms a bridge between $\mathrm{Eu}-$ rope, Asia, and Africa for plants as well as human civilisation (McNeil, 1992; Eastwood et al., 1998; Oğuz, 2004; Magyari et al., 2007), and the regional climate is equally influenced by North Atlantic, Asian, and African climatic forces, resulting in regional differences in the extent, intensity and impact of climatic change (Cullen and deMenocal, 2000; Cullen et al., 2002; Bolle, 2003; Luterbacher, 2006a). The rough topography of the region further increases the complexity of the environmental and climatic systems in the Eastern Mediterranean. These factors, as well as the long history of human impact on the landscape, have resulted in a very complex history of climate-related and anthropogenically driven environmental changes, which may vary strongly from location to location (Behre, 1990; Bottema and Woldring, 1990).

Palaeoecological and palaeoclimatological research provides valuable insights into the length, nature and severity of human impact on the environment, and the interrelatedness of environment, climate and human impact. In Turkey, a relatively low amount of Holocene palaeoecological studies have been performed in comparison with Northern and Western Europe. Furthermore, the focus of many earlier palynological research projects covers a larger time period, focussing on the more lengthy periods of vegetation and climatic change during the Holocene (e.g. van Zeist et al., 1975; Bottema and Woldring, 1984; Roberts et al., 2001). Many earlier records also suffer from a relatively low sampling resolution, and/or possess a chronological framework based on a low number of radiocarbon dates (Table 1), making it difficult to properly identify periods/trends/events which occur on a scale of a few centuries or less. Additionally, records covering the late Holocene in Turkey often have a focus on the Beyşehir Occupation Phase (BO Phase), a period identified in numerous pollen records in the Eastern Mediterranean (e.g. van Zeist et al., 1975; Bottema, 1982; Bottema and Woldring, 1990; Bottema et al., 1993; Triantaphyllou et al., 2009), characterized by signs of intense human impact, particularly arboriculture. This Phase occurred roughly between 3000 and $1300 \mathrm{yr}$ before the present, although the start and end dates can vary quite significantly between sites, even among relatively welldated records. This focus caused the periods preceding and succeeding the BO Phase to receive relatively little attention. Specifically for the region of SW Turkey, where much important pioneering palynological work has been performed by van Zeist et al. (1975), Bottema and Woldring (1984), Eastwood et al. (1998, 1999), Vermoere et al. (2002a, b), Kaniewski et al. (2007a, b, 2008), no palynological records exist which cover the post-BO Phase in detail.
The lack of data concerning the post-BO Phase means that, although there is a wealth of information available concerning Late Holocene climate change in the Eastern Mediterranean (e.g. Luterbacher et al., 2006b, 2012; Hajar et al., 2010), little knowledge is available concerning how important periods of climatic change, such as the Little Ice Age (LIA) or Medieval Climate Anomaly (MCA) influenced vegetation dynamics in Turkey (e.g. Neumann et al., 2007a, b; Kaniewski et al., 2010, 2011a, b), nor how human impact changed due to climate change and/or socioeconomical/political shifts.

The complexity of the climatic systems and cultural history in this geographical region necessitate an understanding of the timing, nature and impact of climatic change on a more local scale. A comparison of any two palaeoecological or paleoclimatological records from the eastern Mediterranean, with the aim of studying the interconnectedness of climate, environment, and human impact, is likely to be problematical, as both locations will be characterized by different climatic and soil conditions, vegetation types, and cultural history. This problem is illustrated in Fig. 1, which shows the largely simultaneous occurrence of the LIA and MCA, but also clearly displaying differing start and end dates for these climatic phenomena. Although these differences may in part be caused by differing sampling resolutions and quality of the chronological framework, these factors are insufficient to explain the full variation in the timing of the various climatic periods.

Thus there are two important gaps in the current knowledge on palaeoecology and palaeoclimatology in Turkey. Firstly there is a temporal gap, and secondly a geographical gap. It is vital to obtain knowledge concerning vegetation and climate change from locations from which data concerning certain time intervals is still lacking. New palaeoecological records from understudied regions such as SW Turkey would provide valuable insights into historical patterns of environmental change and will contribute to the understanding of the interconnections between climate change, vegetation dynamics, and human impact through time.

Bakker et al. (2012) revealed the presence and timing of several late Holocene wet and dry bioclimatic periods in southwest Turkey, coinciding with well-known climatic periods such as the Medieval Climate Anomaly (MCA) and the Little Ice Age (LIA). Although some attention was given to the driving processes behind vegetation change, Bakker et al. (2012) was primarily a technical paper demonstrating the methods by which climatic periods were distinguished in pollen data.

The present paper builds upon these findings, providing a more in-depth analysis of the available data from Gravgaz marsh, and presenting an entirely new record from the nearby Bereket basin, providing new pollen, non-pollen palynomorph, pollen-slide charcoal, and detailed sedimentological records. Both records are supported by a detailed combined chronological framework based on $27 \mathrm{AMS}{ }^{14} \mathrm{C}$ ages. 
Table 1. The main characteristics of a selection of palynological records from Turkey.

\begin{tabular}{|c|c|c|c|c|c|}
\hline Region & Location & Core & First published in & Oldest sample $\left({ }^{14} \mathrm{C}\right.$ yr BP $)$ & \# carbon dates \\
\hline \multirow{10}{*}{$\begin{array}{l}\text { Southwest } \\
\text { Turkey } \\
\text { (Territory of } \\
\text { Sagalassos) }\end{array}$} & Sagalassos: Gravgaz & SA06EP1 & Bakker et al. (2011) & 1850 & 7 \\
\hline & Sagalassos: Bereket & SA09JBDrill02 & Present publication & 2370 & 17 \\
\hline & Sagalassos: Canaklı & & Vermoere et al. (2002b) & unknown & 0 \\
\hline & Sagalassos: Başköy & & Vermoere (2004) & Early Holocene & 1 \\
\hline & Sagalassos: Ağlasun & Core 6 & Vermoere (2004) & 8760 & 5 \\
\hline & Sagalassos: Ağlasun & Core 12 & Vermoere (2004) & 7640 & 5 \\
\hline & Sagalassos: Ağlasun & Core 13 & Vermoere (2004) & 7840 & 2 \\
\hline & Sagalassos: Bereket & BKT1/2 & Kaniewski et al. (2007a, b) & 3260 & 11 \\
\hline & Sagalassos: Gravgaz & G96 & Vermoere et al. (2002b) & 2600 & 7 \\
\hline & Sagalassos: Gravgaz & G99 & Vermoere et al. (2002b) & 2540 & 7 \\
\hline \multirow{11}{*}{$\begin{array}{l}\text { Southwest } \\
\text { Turkey }\end{array}$} & Beyşehir Gölü & I & van Zeist et al. (1975) & 6500 & 2 \\
\hline & Beyşehir Gölü & II & Bottema and Woldring (1985) & 16000 & 1 \\
\hline & Sögüt Gölü & & van Zeist et al. (1975) & 19500 & 2 \\
\hline & Pinarbaşı & & Bottema and Woldring (1984) & 17000 & 2 \\
\hline & Köyceğiz Gölü & & van Zeist et al. (1975) & 5697 & 2 \\
\hline & Gölhisar Gölü & & Eastwood et al. (1999) & 4000 & 8 \\
\hline & Ova Gölü & & Bottema and Woldring (1984) & 6655 & 2 \\
\hline & Hoyran Gölü & & Bottema and Woldring (1984) & 4000 & 1 \\
\hline & Avlan Gölü & & Bottema and Woldring (1984) & unknown & 0 \\
\hline & Elmalı & & Bottema and Woldring (1984) & unknown & 0 \\
\hline & Karamık Bataklı̆̆g & & Bottema and Woldring (1984) & 20000 & 2 \\
\hline \multirow{3}{*}{ West Turkey } & Bafa Gölü & & Knipping et al. (2008) & 4000 & 5 \\
\hline & Manyas Gölü & & Leroy et al. (2002) & 2100 & 2 \\
\hline & Yenişehir & & Bottema and Woldring (1995) & unknown & 0 \\
\hline \multirow{9}{*}{ North Turkey } & Akgöl Adatepe & & Bottema et al. (1993) & 900 & 1 \\
\hline & Küçük Akgöl & & Bottema et al. (1993) & 3900 & 2 \\
\hline & Melen Gölü & & Bottema et al. (1993) & 4000 & 1 \\
\hline & TatlıGölü & & Bottema et al. (1993) & Unknown & 1 \\
\hline & Kaz Gölü & & Bottema et al. (1993) & $>10000$ & 2 \\
\hline & Demiryurt Gölü & & Bottema et al. (1993) & 2000 & 1 \\
\hline & Abant Gölü & & Bottema et al. (1993) & 13580 & 5 \\
\hline & Büyük Gölü & & Bottema et al. (1993) & Unknown & 0 \\
\hline & Seyfe Gölü & & Bottema et al. (1993) & Unknown & 0 \\
\hline \multirow{4}{*}{ Central Turkey } & Tuzla Gölü & & Bottema et al. (1993) & Unknown & 0 \\
\hline & Eski Acıgöl & & Roberts et al. (2001) & 16000 & 16 \\
\hline & Nar Gölü & & England et al. (2008) & 1700 & Varves \\
\hline & Akgöl & & Bottema and Woldring (1984) & 13050 & 3 \\
\hline \multirow{2}{*}{ East Turkey } & Van Gölü & & van Zeist and Woldring (1978) & 13000 & Varves \\
\hline & Van Gölü & & Wick et al. (2003) & 13000 & Varves \\
\hline \multirow{2}{*}{ South Turkey } & Bozova Gölü & & Bottema (2009a) & unknown & 0 \\
\hline & Gölbasi Gölü & & Bottema (2009b) & unknown & 0 \\
\hline
\end{tabular}

The use of more than one location within the same region, each at a different altitude and with a different history of human occupation (Vanhaverbeke and Waelkens, 2003), enables a proper distinction between local and regional trends in environmental change. Comparing the palaeoenvironmental findings with the most recent archaeological findings in the study area enables the first in-depth analysis of the interrelatedness of vegetation, geomorphic processes, climatic change, and human impact from the Late Roman period until (sub)recent times in SW Turkey. Using a variety of numeri- cal analyses on the charcoal and pollen data reveals the relative (un)importance of fire in the post-BO Phase landscape and the relation between fire and vegetation, as well as the general nature and timing of natural succession following a decline in human impact. 


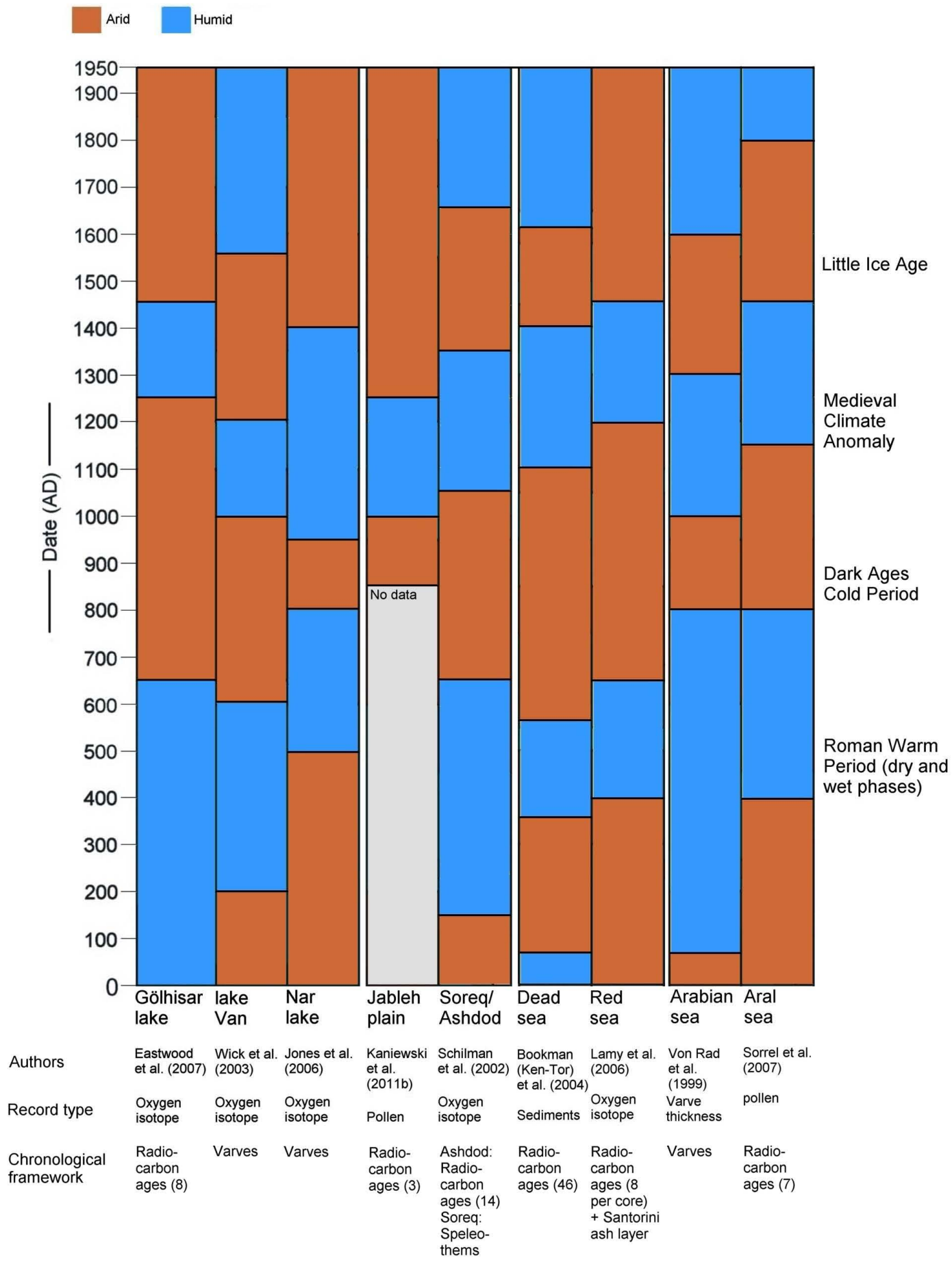

Fig. 1. An overview of the estimated timing of the RWP, DACP, MCA, and LIA, in a selection of climatic records from Europe and the Near East. The general occurrence of these climatic periods throughout the selected records is immediately apparent, as are the differences in the exact start and end dates.

\section{Study sites}

The study area is located within what was once the territory governed by the city of Sagalassos, an important archaeological site in the southwest of Turkey that saw its heydays dur- ing Hellenistic and Roman times, but which remained permanently inhabited until the 13th century (Waelkens, 1993; Waelkens et al., 2000; Poblome and Talloen, 2005; De Cupere et al., 2009; Vionis et al., 2009a, b). The territory ranges in altitude between 800 and $2300 \mathrm{~m}$ a.s.l.(above sea 
level) and is part of the Western Taurus Mountains. The geology of the territory of Sagalassos and the requirements for pollen preservation limit the amount of suitable sites for palynological research. Most basins within the historical territory of Sagalassos have been filled in with several meters of colluvial and alluvial deposits, eventually also during the last three millennia (Six, 2004; Dusar et al., 2011). Furthermore, some basins where marshes, lakes or wetlands persisted were drained over the course of the 20th century. Despite the recent drainage activity, two notable locations remain where usable, late Holocene deposits have been found (Fig. 2). Both sites are located within the upper unit of the Oromediterranean vegetation zone according to van Zeist et al. (1975) and at the highest vegetation zone according to Fontaine et al. (2007), although very little remains of the natural vegetation due to overgrazing and the intensification of agriculture since the 20th century.

\subsection{Gravgaz}

Gravgaz Marsh is located in the bottom of an intramontane basin at an altitude of $1215 \mathrm{~m}$ a.s.l., ca. $25 \mathrm{~km} \mathrm{SW}$ of Sagalassos, and measures approximately 800 by $350 \mathrm{~m}$. It is fed by water sources to the west of the marsh. Water flows through the marsh via two streamlets, disappearing in a karstic outflow east of the marsh. Observations since 1996 show that water levels fluctuate interannually and/or seasonally. As of 1999, the marsh dries up during the summer season. The modern physical and biological setting, the late Holocene sediments and pollen sequences of the marsh have been intensively studied during previous years (Six, 2004; Six et al., 2008; Vermoere et al., 2000, 2002a, b) but no detailed study of vegetation dynamics during the post-BO Phase period had been attempted. The substrate in the basin is composed of limestone and the very clayey ophiolitic mélange of the Lycian Nappe, conglomerates and colluvial deposits.

The vegetation on the hills surrounding the marsh is dominated by shrubs of Quercus coccifera and to a lesser degree by Juniperus excelsa and J. oxycedrus. A pine forest is located on the hillsides southeast of the marsh. The land around the marsh is used for the cultivation of cereals and chick peas. Land not used for crop cultivation is grazed by cattle (mainly goats).

The marsh itself is well vegetated and features a patchy vegetation pattern, dominated by Scirpus lacustris, in both wetter and dryer parts. The streamlets feature Carex riparia, Typha latifolia and Sparganium erectum. The transitional zone between the fields and the marshlands is characterized by Alisma plantago/aquatica, A. Lanceolata, Butomus Umbellatus, Lythrum salicaria, Plantago major, Cirsium arvense and Agrostis gigantea. The other edges are characterized by grasses such as Lolium perenne and Hordeum murinum.

\subsection{Bereket}

The intramontane Bereket Basin is located at 1410$1430 \mathrm{~m}$ a.s.l., about $200 \mathrm{~m}$ higher and at a distance of ca. $11 \mathrm{~km} \mathrm{SW}$ from Gravgaz. The site is located $300 \mathrm{~m}$ downstream of the source of the Aykirdak Deresi, nowadays a canalized river at the southern limit of a former 35 ha marsh. This marsh, situated in the lowest parts of a flat valley bottom, was drained in the 1960s. Apart from the Pliocene marls exposed on the western slopes, the substrate types are identical with that at Gravgaz: limestone and the clayey ophiolitic mélange of the Lycian Nappe dominate, with gravel fans and colluvial deposits at the footslopes. For details about the modern physical setting the authors refer to Kaniewski et al. (2007b). Nowadays the valley bottom and adjacent lower slopes are used for the cultivation of cereals and chick peas, and occasionally sugar beets in the former marsh area. Other cultivars include Castanea sativa, Prunus persica, Prunus avium and Juglans regia. Vitis vinifera occurs sporadically. The overgrazed hillsides are covered by degraded Juniperus excelsa woodland in the southeast area, or partially degraded J. excelsa-Cedrus libani woodland in the northwest area. Other constituents of these degraded or partially degraded woodlands are Quercus coccifera shrubs and Juniperus oxycedrus. The last remaining marshes are covered in Carex riparia, Scirpus lacustris, Typha angustifolia, Sparganium spp. and Butomus umbellatus with limited Populus nigra cultivation. A low amount of Salix spp. and Fraxinus angustifolia occurs along the borders of the remaining marshlands. Late Holocene deposits have been previously studied by Kaniewski et al. (2007a, b, 2008). Unfortunately, the limitations of the chronology in the upper part of their core BKT1/2 made it impossible to study the vegetation and sediment history from the 7th century onwards in any detail.

\subsection{Climate}

Anatolia is located between humid regions in the north and arid regions in the south. The principal weather systems in the region originate from the Atlantic Ocean, passing over Europe or the Mediterranean Sea. Relatively cold air leaving Turkey moves in a southern direction, colliding with warmer Saharan air over Cyprus, forming a front along which winter storms may travel eastward, bringing rain and snow into the Middle East (LaFontaine and Bryson, 1990). Being a climatic transition zone, the Eastern Mediterranean is sensitive to fluctuations in natural environmental parameters, such as rainfall, temperature, vegetation types, the origin and pattern of storm tracks, and the location of the desert boundary (Bar-Matthews et al., 1999). The most dominant source of climate variability in the wider region is the North Atlantic Oscillation (NAO). The NAO accounts for onethird of the total variance in sea-level pressure and 20 to 60 percent of the December-March temperature and rainfall variability from Greenland and Europe to the Eastern 


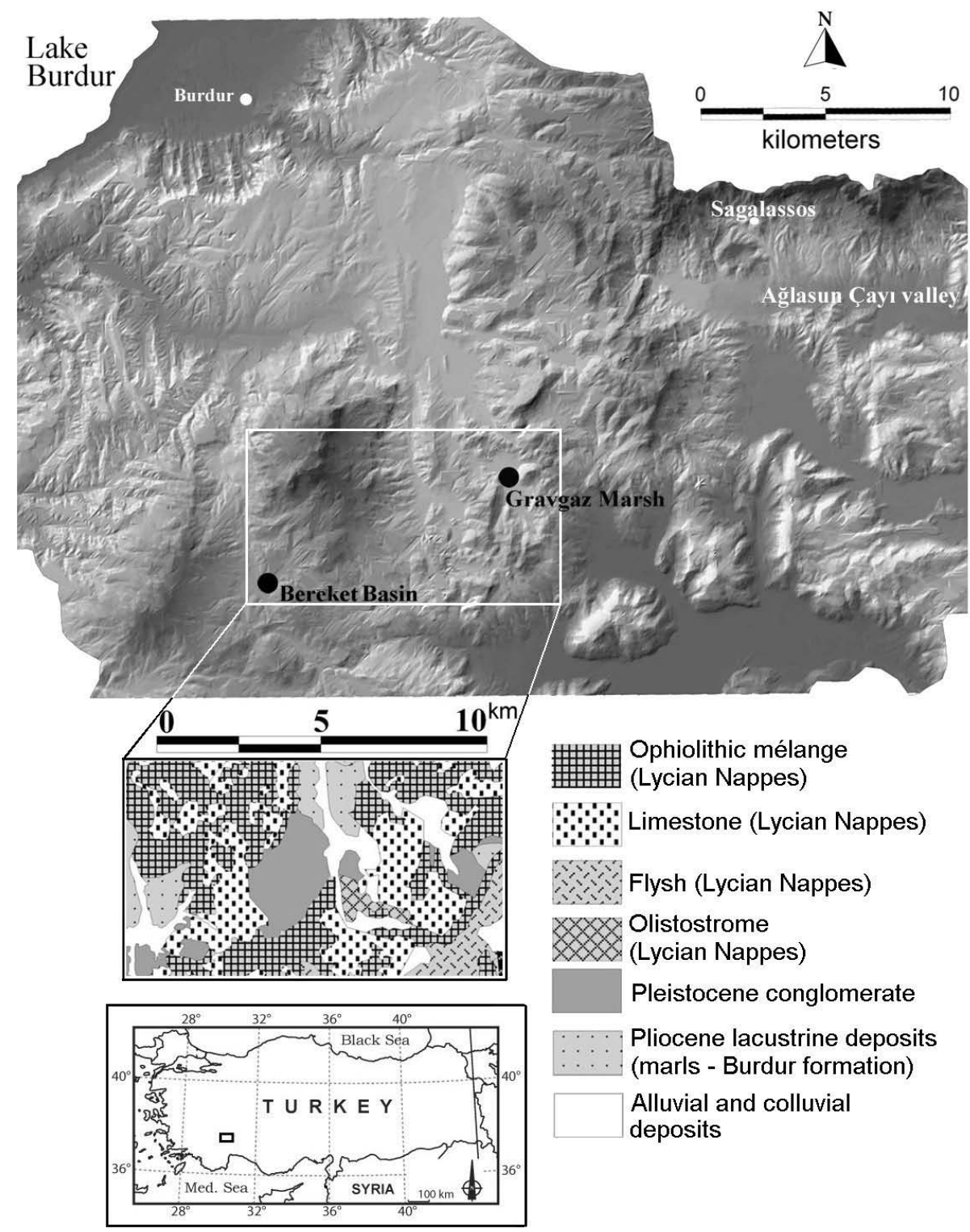

Fig. 2. A DEM and geological map of the main part of the territory of Sagalassos with the position of the coring sites.

Mediterranean (Luterbacher et al., 2009). Fluctuations in the NAO may result in surface winds and wintertime storms, moving across the North Atlantic from west to east, being stronger or weaker than usual. As a result, winters in the Eastern Mediterranean will be cooler and drier or warmer and wetter, respectively. Past changes in climatic conditions over the North Atlantic, such as described by Bond et al. (1997, 2001), may have influenced the NAO and thus the Middle Eastern winter climate (Cullen et al., 2002). Unal et al. (2003) classified the climate of the region, in which the study area is located, as having a Central Anatolian climate. In reality, the high altitude and location in respect to the main mountain ridges causes the study area to have an Oromediterranean climate, characterized by cold, wet win- ters and dry, hot summers. The climate can be described as subhumid and cold to very cold, with four cold months and one very cold month. Recent climatic data from the town of Ağlasun is displayed in Table 2.

\section{Materials and methods}

\subsection{Coring and chronology}

The data from Gravgaz originates from the top $3.5 \mathrm{~m}$ of an $8 \mathrm{~m}$ sediment core (SA06EP1) drilled in the middle of the marsh, where erosion is expected to be minimal. This core, located at $30.403578^{\circ} \mathrm{E}, 37.584248^{\circ} \mathrm{N}$, was drilled with a \pm 0.5 -m-long Dachnowsky sampler. The data from Bereket 
Table 2. A summery of modern-day climatic conditions in the study area as collected by the weather station in Ağlasun $\left(37^{\circ} 39^{\prime} \mathrm{N} 30^{\circ} 32^{\prime} \mathrm{E}\right)$. The data presents average values of data collected between 1972 and 1992 (Aðlasun Meteorology Station. Turkish State Meteorological Service, Ankara).

\begin{tabular}{|c|c|c|c|c|c|c|c|c|c|c|c|c|c|}
\hline & Jan & Feb & Mar & Apr & May & Jun & Jul & Aug & Sep & Okt & Nov & Dec & Annual \\
\hline Mean Maxir & 11.79 & 13.69 & 19.10 & 22.61 & 27.20 & 30.57 & 33.09 & 32.96 & 30.51 & 27.08 & 20.12 & 14.11 & 23.57 \\
\hline Mean I & -9.15 & -9.14 & -6.44 & -0.60 & 1.98 & 6.18 & 9.24 & 9.23 & 4.72 & -0.11 & -4.70 & -7.30 & -0.51 \\
\hline Mean A & 1.15 & 1.83 & 5.17 & 9.26 & 13.80 & 18.26 & 21.45 & 20.83 & 16.98 & 11.66 & 6.18 & 2.91 & 10.79 \\
\hline Total precipitation (mm) & 109.82 & 97.97 & 70.77 & 87.47 & 69.77 & 41.05 & 17.82 & 20.32 & 18.68 & 63.81 & 67.03 & 99.76 & 764.25 \\
\hline
\end{tabular}

originates from a $6.3 \mathrm{~m}$ long sediment core (SA09JBDrill02) drilled near the south bank of the Aykirdak Deresi, using an Eijkelkamp percussion drill, containing a $1 \mathrm{~m}$ long core sampler with a one meter long PVC sample tube. This core is located at $30.293076^{\circ} \mathrm{E}, 37.541241^{\circ} \mathrm{N}$. The agedepth model for the Gravgaz core is based on ten AMS ${ }^{14} \mathrm{C}$ ages. Seven radiocarbon ages were attained by radiocarbon dating material from the pollencore SA06EP1. Three additional dates were attained by re-calibrating additional radiocarbon dates of core SA00EP03, drilled several decimetres from core SA06EP1, and studied by Six (2004) and Six et al. (2008). The age-depth model for the Bereket core is based on $17 \mathrm{AMS}{ }^{14} \mathrm{C}$ ages.

The ages were calibrated with the IntCal09 calibration curve (Reimer et al., 2009), using the BCal calibration program (Buck et al., 1999; http://bcal.sheffield.ac.uk). BCal uses Bayesian statistics allowing for the implementation of a priori knowledge into the age-depth model, e.g. that ages higher in the core are younger than ages lower in the core. When ages with overlapping calibrated probability distributions occur, $\mathrm{BCal}$ produces posterior probability distributions with non-overlapping modes, essentially wiggle-matching the ages to the calibration curve. The Bcal software also provides the option to perform an analysis of possible outliers.

The material used for radiocarbon dating consisted of macroscopic charcoal fragments and terrestrial plant seeds, collected using a $200 \mu \mathrm{m}$ sieve. The material used for the radiocarbon dating on core SA00EP3 consisted of soil organics. Details of the radiocarbon dates collected for the two cores are displayed in Table 3.

The sedimentological parameters discussed in the present paper are: $(\mathrm{OM})$ content, calcium carbonate $(\mathrm{CC})$ content, and other detritic matter content. All parameters are expressed as weight percentages (wt\%). OM content is calculated using the weight loss after oxidation with $\mathrm{H}_{2} \mathrm{O}_{2}$. $\mathrm{CC}$ content was calculated using the weight loss after treating the samples with $\mathrm{HCl} 10 \%$. The remaining matter is deemed "other detritic matter". The sedimentological data for Gravgaz originates from core SA00EP3 and was previously published in Six (2004).

\subsection{Pollen and non-pollen palynomorphs}

Pollen samples were isolated from the core using the standard technique of Faegri and Iversen (1989). The samples were studied under a 400X and 1250X magnification (using oil immersion) under a Leitz microscope. 50 samples were taken from the Gravgaz sediment core, resulting in a mean sample interval of $6.7 \mathrm{~cm}$ or $46.6 \mathrm{yr}$ per $\mathrm{cm} .44$ samples were taken from the Bereket sediment core, resulting in a mean sample interval of $13.5 \mathrm{~cm}$ or $56.9 \mathrm{yr}$ per $\mathrm{cm}$.

Identifications of pollen types were performed using Beug (2004), Moore et al. (1991) and Reille (1992). Identifications of non-pollen palynomorphs were performed using Kuhry (1997), Pals et al. (1980), van Geel et al. (1981, 1983) and van der Wiel (1983). Pollen conservation was assessed by summing the corroded, degraded, broken and crumpled pollen in a "deterioration assemblage" (Cushing, 1967).

Percentage diagrams were constructed using TILIA and TGVIEW software (Grimm, 1991). Pollen data were grouped according to the NJ-derived PDVPs with the cultivated species displayed separately, and expressed as relative frequencies (\%) of the pollen sum, which includes herbaceous land plants, trees and shrubs.

Anthropogenic activity is assessed by studying the primary anthropogenic indicator species as determined for the region by Bottema and Woldring (1990). Establishment of meadow steppe on land previously occupied by forest or agriculture is seen as an indication of pastoralism. Furthermore, remains of coprophilous fungi may indicate grazing by herbivores on the sample site itself (van Geel et al., 2003; van Geel and Aptroot, 2006). All numerical analyses were performed using the computer program PAST (http://folk.uio. no/ohammer/past/).

\subsection{Numerical analyses}

To investigate short- and long-term effect of fires on vegetation, as well as the general pattern of succession following a natural or anthropogenic disturbance, all pollen, and micro and macro charcoal counts were recalculated to concentrations. These were divided by the total regional particle (nonlocal pollen and charcoal particle) concentration in order to counter the obscuring influence of changes in sedimentation rates. Charcoal and pollen types were grouped using Neighbour Joining (NJ) analysis. NJ analysis was initially designed 
Table 3. List of AMS ${ }^{14} \mathrm{C}$ ages from charcoal samples from core SA06EP1 (Gravgaz Marsh), and core SA09JBDrill01 (Bereket Basin). Ages are calibrated using the IntCal09 calibration curve. Calibrated ages are given as 1 sigma and 2 sigma probabilities, using the BCal online software package (Buck et al., 1999). The age-depth relationship of the Gravgaz marsh core is augmented by the four topmost radiocarbon ages from core SA00EP03, collected on the same location.

\begin{tabular}{|c|c|c|c|c|c|c|c|c|c|}
\hline $\begin{array}{r}\text { Depth } \\
\mathrm{cm}\end{array}$ & Sample Type & Lab codes & $\begin{array}{r}\delta^{13} \mathrm{C} \\
(\% \circ \mathrm{PDB})\end{array}$ & Measured age & $\begin{array}{r}\text { Conventional } \\
\text { age }\end{array}$ & $95 \%$ lower & $95 \%$ upper & $69 \%$ lower & $69 \%$ upper \\
\hline 39 & Charred material & Beta- 257413 & $\mathrm{n} / \mathrm{a}^{*}$ & $\mathrm{n} / \mathrm{a}$ & $100 \pm 40 \mathrm{BP}$ & 1680 & 1940 & 1690 & 1920 \\
\hline 88 & Seeds & Beta-257414 & -24.9 & $370 \pm 40 \mathrm{BP}$ & $370 \pm 40 \mathrm{BP}$ & 1450 & 1640 & 1460 & 1630 \\
\hline 133 & Charred material & Beta-263584 & -23.2 & $860 \pm 40 \mathrm{BP}$ & $890 \pm 40 \mathrm{BP}$ & 1030 & 1210 & 1040 & 1190 \\
\hline 140 & Charred material & Beta- 257420 & -24.3 & $1010 \pm 40 \mathrm{BP}$ & $1020 \pm 40 \mathrm{BP}$ & 970 & 1150 & 990 & 1040 \\
\hline 147 & Charred material & Beta-263585 & -24.7 & $1160 \pm 40 \mathrm{BP}$ & $1160 \pm 40 \mathrm{BP}$ & 860 & 1010 & 920 & 980 \\
\hline 222 & Charred material & Beta-257421 & -21 & $1030 \pm 40 \mathrm{BP}$ & $1100 \pm 40 \mathrm{BP}$ & 800 & 990 & 890 & 960 \\
\hline 277 & Charred material & Beta- 257422 & -22.5 & $1700 \pm 40 \mathrm{BP}$ & $1740 \pm 40 \mathrm{BP}$ & 210 & 410 & 240 & 340 \\
\hline \multicolumn{10}{|c|}{ Core SA00EP03 } \\
\hline 233 & Bulk soil sample & GrN-26339 & $\mathrm{n} / \mathrm{a}$ & $\mathrm{n} / \mathrm{a}$ & $1760 \pm 60 \mathrm{BP}$ & \multicolumn{4}{|c|}{ Posterior probability of sample being an outlier: $100 \%$} \\
\hline 282 & Bulk soil sample & GrA-19896 & $\mathrm{n} / \mathrm{a}$ & $\mathrm{n} / \mathrm{a}$ & $1760 \pm 50 \mathrm{BP}$ & 130 & 350 & 180 & 300 \\
\hline 386 & Bulk soil sample & GrA-19898 & $\mathrm{n} / \mathrm{a}$ & $\mathrm{n} / \mathrm{a}$ & $2020 \pm 50 \mathrm{BP}$ & -160 & 80 & -60 & 60 \\
\hline \multicolumn{10}{|c|}{ Bereket } \\
\hline 43 & Plant remains & Beta-287853 & -27.8 & $360 \pm 40 \mathrm{BP}$ & $310 \pm 40 \mathrm{BP}$ & 1480 & 1660 & 1520 & 1650 \\
\hline 170 & Plant remains & Beta-287855 & -25.9 & $770 \pm 40 \mathrm{BP}$ & $760 \pm 40 \mathrm{BP}$ & 1210 & 1300 & 1230 & 1280 \\
\hline 207 & Charred material & Beta-287854 & -29 & $1020 \pm 40 \mathrm{BP}$ & $950 \pm 40 \mathrm{BP}$ & 1020 & 1170 & 1030 & 1160 \\
\hline 234 & Charred material & Beta-295432 & $\mathrm{n} / \mathrm{a}^{*}$ & $\mathrm{n} / \mathrm{a}$ & $1190 \pm 30 \mathrm{BP}$ & 780 & 900 & 820 & 890 \\
\hline 238 & Charred material & Beta- 280822 & -27.4 & $1230 \pm 40 \mathrm{BP}$ & $1190 \pm 40 \mathrm{BP}$ & 770 & 890 & 800 & 860 \\
\hline 270 & Plant remains & Beta-295434 & $\mathrm{n} / \mathrm{a}^{*}$ & $\mathrm{n} / \mathrm{a}$ & $1220 \pm 30 \mathrm{BP}$ & 720 & 870 & 770 & 830 \\
\hline 283 & Charred material & Beta-295433 & -23 & $1180 \pm 30 \mathrm{BP}$ & $1210 \pm 30 \mathrm{BP}$ & 690 & 830 & 720 & 800 \\
\hline 305 & Charred material & Beta-287856 & -25.1 & $1420 \pm 40 \mathrm{BP}$ & $1420 \pm 40 \mathrm{BP}$ & \multicolumn{4}{|c|}{ Posterior probability of sample being an outlier: $85 \%$} \\
\hline 319 & Charred material & Beta-280821 & -27.2 & $1460 \pm 40 \mathrm{BP}$ & $1420 \pm 40 \mathrm{BP}$ & \multicolumn{4}{|c|}{ Posterior probability of sample being an outlier: $67 \%$} \\
\hline 331 & Charred material & Beta-274769 & $\mathrm{n} / \mathrm{a} *$ & $\mathrm{n} / \mathrm{a}$ & $1350 \pm 40 \mathrm{BP}$ & 650 & 770 & 660 & 700 \\
\hline 361 & Charred material & Beta-274770 & -24.7 & $1380 \pm 40 \mathrm{BP}$ & $1380 \pm 40 \mathrm{BP}$ & 620 & 690 & 640 & 670 \\
\hline 391 & Charred material & Beta-295435 & -25 & $1740 \pm 30 \mathrm{BP}$ & $1740 \pm 30 \mathrm{BP}$ & \multicolumn{4}{|c|}{ Posterior probability of sample being an outlier: $100 \%$} \\
\hline 463 & Uncharred wood & Beta-280824 & -24 & $1390 \pm 40 \mathrm{BP}$ & $1410 \pm 40 \mathrm{BP}$ & 600 & 670 & 620 & 660 \\
\hline 493 & Charred material & Beta-295437 & $\mathrm{n} / \mathrm{a}^{*}$ & $\mathrm{n} / \mathrm{a}$ & $1500 \pm 30 \mathrm{BP}$ & 440 & 620 & 540 & 600 \\
\hline 507 & Plant remains & Beta-280823 & -25.9 & $1620 \pm 40 \mathrm{BP}$ & $1610 \pm 40 \mathrm{BP}$ & 380 & 550 & 410 & 530 \\
\hline 525 & Plant remains & Beta-295436 & -25 & $1740 \pm 30 \mathrm{BP}$ & $1740 \pm 30 \mathrm{BP}$ & 250 & 390 & 290 & 390 \\
\hline 582 & Charred material & Beta-287857 & -25.8 & $2450 \pm 40 \mathrm{BP}$ & $2440 \pm 40 \mathrm{BP}$ & -780 & -410 & -760 & -490 \\
\hline
\end{tabular}

* Sample was too small for a separate ${ }^{13} \mathrm{C} /{ }^{12} \mathrm{C}$ ratio and AMS analysis.

as a bottom-up clustering method for reconstructing phylogenetic trees (Saitou and Nei, 1987). In this case the NJ technique was adjusted and used to measure ecological distances between plant taxa (Baxter, 1994; Kaniewski et al., 2011b).

The length of the branches on the resulting tree can be interpreted as the ecological distances between groups of taxa. The similarity measure was "Correlation" and the root was "Final Branch". In contrast to cluster analysis, Neighbour Joining keeps track of nodes on a tree rather than taxa or clusters of taxa. As a consequence, the NJ is less useful for revealing the general relationship between plant taxa and environmental conditions, but gives a better representation of the succession in the vegetation through time. Adding charcoal concentration to the data set reveals which group of plant taxa is most affected by fire, and which group is able to colonize the burned landscape.

The groupings in the resulting tree diagram should not be interpreted to resemble separate vegetation types, but rather plants from different vegetation types at different locations around the sample sites, which thrive or decrease at the same time. The resulting clusters are termed Pollen Derived Vegetation Patterns (PDVPs). The ecological significance of each PDVP can be assessed by studying the most important taxa in each PDVP and the vegetation types they are associated with. The top four samples from the Bereket core were omitted due to the fact that this part of the sediment has been located above the present water table since the draining of the marsh in the 1960s, and is therefore considered unusable for palaeoecological research.

Linear detrended cross correlations ( $p=0.05)$ were computed to study the ecological relationship between each PDVP and charcoal concentration. Linear detrended crosscorrelation concerns the time alignment of two time series by means of the correlation coefficient (CC). Positive and negative correlations (with +0.5 and -0.5 as significant threshold) are considered when the lag is 0 or realistically small. A 
significant positive or negative correlation between charcoal and PDVP concentrations may indicate that the increased importance of this PDVP may be related to an increased fire activity near the sample site or in the wider vicinity. Null values indicate a complete lack of correlation.

The occurrence and timing of peaks in the charcoal concentration record is used to estimate the relative importance of fire in the post-BO Phase landscape around both sample sites. Using peaks in charcoal accumulation and concentration to estimate the timing of fire periods and fire episodes is complicated by the fact that such records are complex and non-stationary, their mean and variance changing over time (Clark et al., 1996; Clark and Patterson, 1997; Higuera et al., 2010). Higuera et al. $(2007,2010)$ suggest that the two most important processes that cause non-stationarity in charcoal records are changes in the fire regime and changes in the efficiency of charcoal delivery. The former process may be caused by changes in the rate of burning, the intensity of fires and the type of vegetation that is burned. The latter process generally applies to changes in the efficiency of charcoal delivery to the lake centre due to changing rates of slope wash and/or within-lake redeposition (Higuera et al. 2010). The pollen records studied in this paper originate from marshes and colluvial deposits, rather than a lake. However, the processes described by Higuera et al. (2010) lead to changes in sediment accumulation rates, which may cause long-term trends in charcoal records unrelated to changes in the fire regime.

In order to overcome the aforementioned problems, a statistical approach is used to distinguish between truly anomalous charcoal concentrations in the sediment, indicating fire events, and peaks in charcoal concentration that may be the result of increased sedimentation rates. Pollen slide charcoal particles $(50-200 \mu \mathrm{m})$ and larger charcoal remains (200$2000 \mu \mathrm{m}$ ) were counted and summed. A visual observation of both cores did not reveal the presence of any charcoal layers. Sieving the samples indicated that the amount of charcoal particles bigger than $2000 \mu \mathrm{m}$ was minimal. These observations led to the assumption that fires did not occur on or near the sample sites themselves.

Charcoal accumulation rates (CHAR) were computed using the CharAnalysis software, a program for analysing sediment-charcoal records with the goal of peak-detection to reconstruct fire histories (For more info on CharAnalysis see http://sites.google.com/site/charanalysis/; Higuera et al., $2007,2010)$. Charcoal data were decomposed into a low frequency background component (Cbackground), and a peak component (Cpeak). A locally defined threshold was used to identify fire events. Cbackground was estimated using a moving median, using a $150 \mathrm{yr}$ window width. Peak components were obtained by subtracting Cbackground from the interpolated CHAR (Cinterpolated), which corresponded to a re-sampling record of the char series using the median accumulation rate. A threshold value was calculated using the Zero-Mean Gaussian and Gaussian Mixture Model. Fire events, indicating fires occurring in the landscape around the sample site, were identified when the CHAR of a single sample exceeded the background CHAR by the threshold ratio (Power et al., 2006). When multiple fire events occur in a short time span, they are referred to as a fire period. Fire frequencies were calculated by summing the total number of fires within a 1000-yr period, and then smoothing this series with a Lowess smoother.

Such analyses have two important limitations. CharAnalysis may have difficulty recognizing fire events when these are immediately followed by a sedimentation event. Such processes have been described and discussed around the Adriatic Sea, Romania, Ukraine, and in Bereket itself (Bodnariuc et al., 2002; Oldfield et al., 2003; Huhmann et al., 2004; Kaniewski et al., 2008). In order to check for fire episodes that the numerical analyses might have missed, the untransformed charcoal concentration data are compared with the core chronology and the sedimentological record, in order to check for anomalously high charcoal percentages immediately preceding episodes of rapid sedimentation. A second limitation is that such analyses are best applied to continuous records. Applying such a numerical analysis on a discontinuous record, such as the present two, may result in some fire episodes being missed, the chances of omitting a fire event growing as the interval between two charcoal samples increases in size. However, the implementation of a CHAR analysis is still of use when applied to a discontinuous record. Even if some individual regional fire events are missed, a longer $50-100 \mathrm{yr}$ period characterized by many fires, as occurred several times during the BO Phase in the study area (Kaniewski et al., 2008) may still be detected.

\section{Results}

\subsection{Core chronology and sediments}

Age-depth curves, lithological information, and curves displaying the $\mathrm{OM}$ content and $\mathrm{CC}$ content are displayed in Fig. 3. Ages of individual pollen samples were estimated using an interpolation/extrapolation assuming constant sedimentation rates between two individual calibrated radiocarbon dates. The methods used in the AMS radiocarbon dating procedure, as well as the calculations used for estimating the ages of samples in between two radiocarbon dates, introduce a measure of uncertainty concerning the accuracy of the ages presented in the present paper. All ages in the text, insofar as they apply to the Bereket and Gravgaz records, are therefore rounded to the decadal level. In the discussion chapter, the use of years is largely eschewed in favour of mentioning the century and an indication of which part of that century a certain phenomenon is estimated to have taken place (e.g. the early/mid/late-10th century AD). 

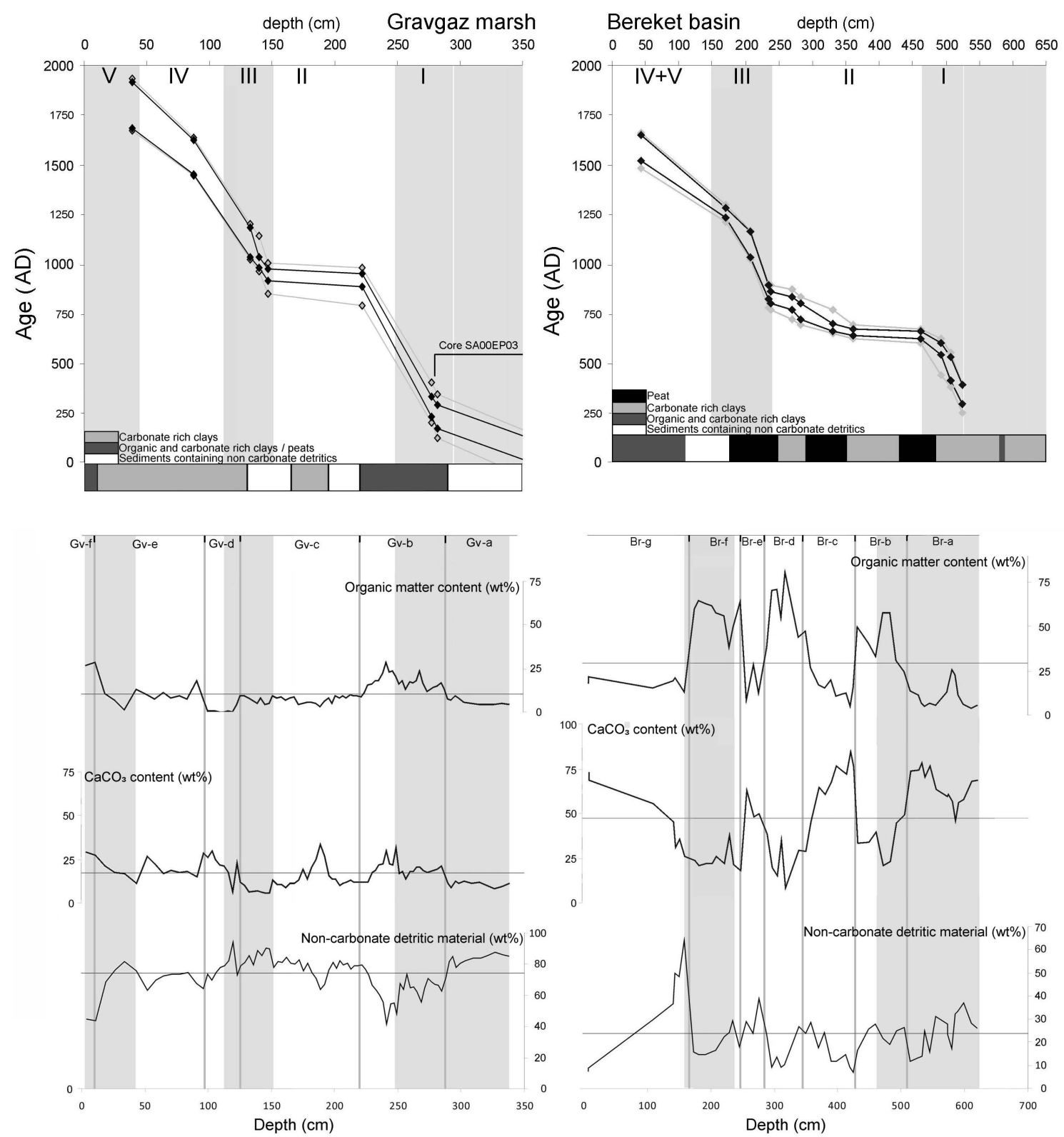

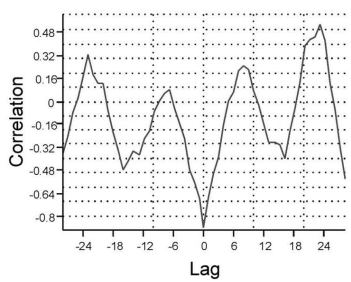

$\mathrm{OM}$ content versus $\mathrm{CC}$ content

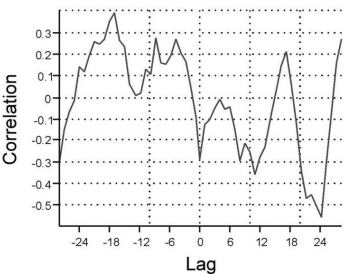

OM content versus non-carbonate detritic matter

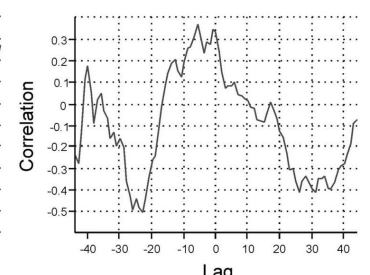

$\mathrm{OM}$ content versus $\mathrm{CC}$ content

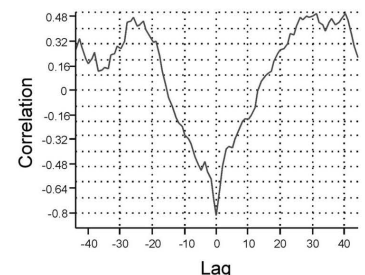

OM content versus non-carbonate

Fig. 3. Top: age-depth curves for Gravgaz core SA06EP1 (left) and Bereket SA09JBDrill01 (right). Middle: an overview of OM content, CC content, and pollen concentration and preservation. Bottom: correlograms displaying the correlation between OM content of the sediments versus CC content, and non-carbonate detritic matter content. Grey bars indicate a subdivision into bioclimatic periods (Bakker et al., 2012). $\mathrm{I}=$ Mid-3rd century - mid-7th century AD Wet Period and earlier. II = Mid-7th century - mid-10th century AD dry period. III = Mid-10th century - mid-13th century AD Wet Period. IV and V= Mid-13th century dry period until recent. The vertical lines in the middle graphs indicate the division of the sediment records into different sedimentological units (see Table 4). 


\subsubsection{Gravgaz marsh}

For Gravgaz, nine out of ten ages from core SA06EP1 and SA00EP03, ranging between cal. $20 \mathrm{BC}$ at $386 \mathrm{~cm}$ and cal $1800 \mathrm{AD}$ at $39 \mathrm{~cm}$, are in chronological order. One age was determined to be an outlier using the Outlier Analysis of $\mathrm{BCal}$ and is subsequently omitted from the age-depth model (Table 3). The lithological sequence is composed of seven units: two units of $\mathrm{CC}$ rich clays, two units dominated by non-carbonate detritics, and two units characterized by organic clays. The age of the base of the core at $339 \mathrm{~cm}$ is calculated at cal $90 \mathrm{AD}$.

The chronology implies the following non-densitycorrected accumulation rates: $4.0 \mathrm{~mm} \mathrm{yr}^{-1}$ for the 339 $282 \mathrm{~cm}$ interval, ca. $1 \mathrm{~mm} \mathrm{yr}^{-1}$ for the $282-222 \mathrm{~cm}$ interval,

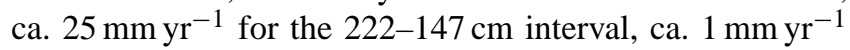
for the $147-88 \mathrm{~cm}$ interval, and $1.9 \mathrm{~mm} \mathrm{yr}^{-1}$ for the 88 $39 \mathrm{~cm}$ interval. The lithological column, mainly clays and fine silts, is composed of $74 \mathrm{wt} \%$ non-carbonate detritics, followed by $16 \mathrm{wt} \% \mathrm{CC}$ and $10 \mathrm{wt} \% \mathrm{OM}$. There is a statistically insignificant positive cross correlation (CC: 0.31 ) between $\mathrm{OM}$ and $\mathrm{CC}$ content, and a strong negative cross correlation (CC: -0.81 ) between $\mathrm{OM}$ and non-carbonate detritics (Fig. 3). The core can be subdivided into six lithological units, which are described in Table 4.

\subsubsection{Bereket basin}

The seventeen AMS ages for core SA09JBDrill02 range between cal $610 \mathrm{BC}$ at $582 \mathrm{~cm}$, and cal $1580 \mathrm{AD}$ at $43 \mathrm{~cm}$ (Fig. 3, Table 3). The oldest age at depth $582 \mathrm{~cm}$ is in chronological order, but its validity is questionable when taking into account the age-depth curve of the well-dated cores BKT2 and BKT1 (Kaniewski et al., 2007a), situated in the fan deposits forming the valley bottom at respectively $440 \mathrm{~m}$ and $420 \mathrm{~m}$ upstream from core SA09JBDrill01 (see Table 5). Three other ages were determined to be outliers using the Outlier Analysis of $\mathrm{BCal}$ and therefore omitted from the age-depth model (Table 3). The extrapolated age of the core bottom at $622 \mathrm{~cm}$ is cal $420 \mathrm{BC}$.

Core SA09JBDrill02 is situated in a depression which acted as a swale, enabling peat growth and peat conservation. Additional cores have shown that the area of peat growth is elongated in an east-west direction and is closely connected to the upper valley of the Aykirdak Deresi River, which flows parallel to the toe of a large fan dipping to the south. It is likely that the valley was created by the incision of this river. The lithological sequence shows a clear contrast between a brownish black compact clay $(7.5 \mathrm{YR} 3 / 1)$ at $639-629 \mathrm{~cm}$, and a light grey softer clay (10 YR 7/1) from 622 till $500 \mathrm{~cm}$, so that the maximum incision may be situated at a core depth of ca. $6.3 \mathrm{~m}$. The age of the incision can be safely situated in the age range ca. cal $330 \mathrm{AD}(1740 \pm 30 \mathrm{BP}$ - Beta-295436; depth $525 \mathrm{~cm}$ in this core), and ca. cal $320 \mathrm{BC}(2230 \pm 40 \mathrm{BP}$
- Beta-213851; depth $783 \mathrm{~cm}$ in core BKT2 situated in the older fan deposits).

The lithological sequence until $630 \mathrm{~cm}$ is composed of seven lithological units described in Table 4. The texture of all detritic units are clays and fine silts. The chronology implies the following non-density-corrected accumulation rates: $1.4 \mathrm{~mm} \mathrm{yr}^{-1}$ for the $622-463 \mathrm{~cm}$ interval, > $100 \mathrm{~mm} \mathrm{yr}^{-1}$ for the $463-361 \mathrm{~cm}^{-1 n t e r v a l,} 7 \mathrm{~mm} \mathrm{yr}^{-1}$ for the $283-238 \mathrm{~cm}$ interval, and $4.2 \mathrm{~mm} \mathrm{yr}^{-1}$ for the $170-43 \mathrm{~cm}$ interval. The top $150 \mathrm{~cm}$ of the sediment core, characterized by a dark brown colour, is currently located above the present water table as water levels dropped after the marsh was drained in the 1960s. The lithological column is composed of $47 \mathrm{wt} \% \mathrm{CC}, 30 \mathrm{wt} \% \mathrm{OM}$, and $23 \mathrm{wt} \%$ non-carbonate detritics. Sediments with high OM content are concentrated in the peat deposits between ca. 500 and $170 \mathrm{~cm}$. There is a strong negative correlation between $\mathrm{OM}$ and $\mathrm{CC}$ content. No significant correlation exists between $\mathrm{OM}$ and other detritic matter content (Fig. 3).

\subsection{Taphonomy}

Pollen concentration and preservation for both cores are displayed in Fig. 4. Pollen preservation is high in both cores, with an average of $70 \%$ of the pollen undamaged. There is no relation between the percentages of corroded/damaged pollen on the one hand and the sediment types and sedimentation rate on the other hand.

The average pollen concentration for both cores is high: 17010 pollen/gram in the Gravgaz core, and 18400 pollen/gram in the Bereket core. Pollen concentrations are generally stable, although each record shows a single peak value. These peaks do not coincide, indicating they result from a local short-term disturbance in the sedimentation of unknown origin. As the focus of the present paper lies with long-term vegetation trends, such individual peak values are of no relevance. For Gravgaz, no further distinct deviations in indeterminable, damaged, or corroded pollen occur. The pollen concentration in Bereket fluctuates, higher pollen concentrations corresponding to increased OM content in the sediment.

\subsection{Numerical analyses}

\subsubsection{Neighbour Joining}

Results of the NJ analyses and cross-correlograms are displayed in Fig. 5. Differences in the distribution of taxa between both cores are assumed to represent differing local environmental conditions. For Gravgaz marsh, six PDVPs were defined by the $\mathrm{NJ}$ analysis performed on the pollen and charcoal data. Charcoal concentration is included in GVZ2. This PDVP is associated with taxa indicative of mixed deciduous woodlands and includes several cultivated trees. This PDVP is bracketed by others indicative of cereal cultivation 


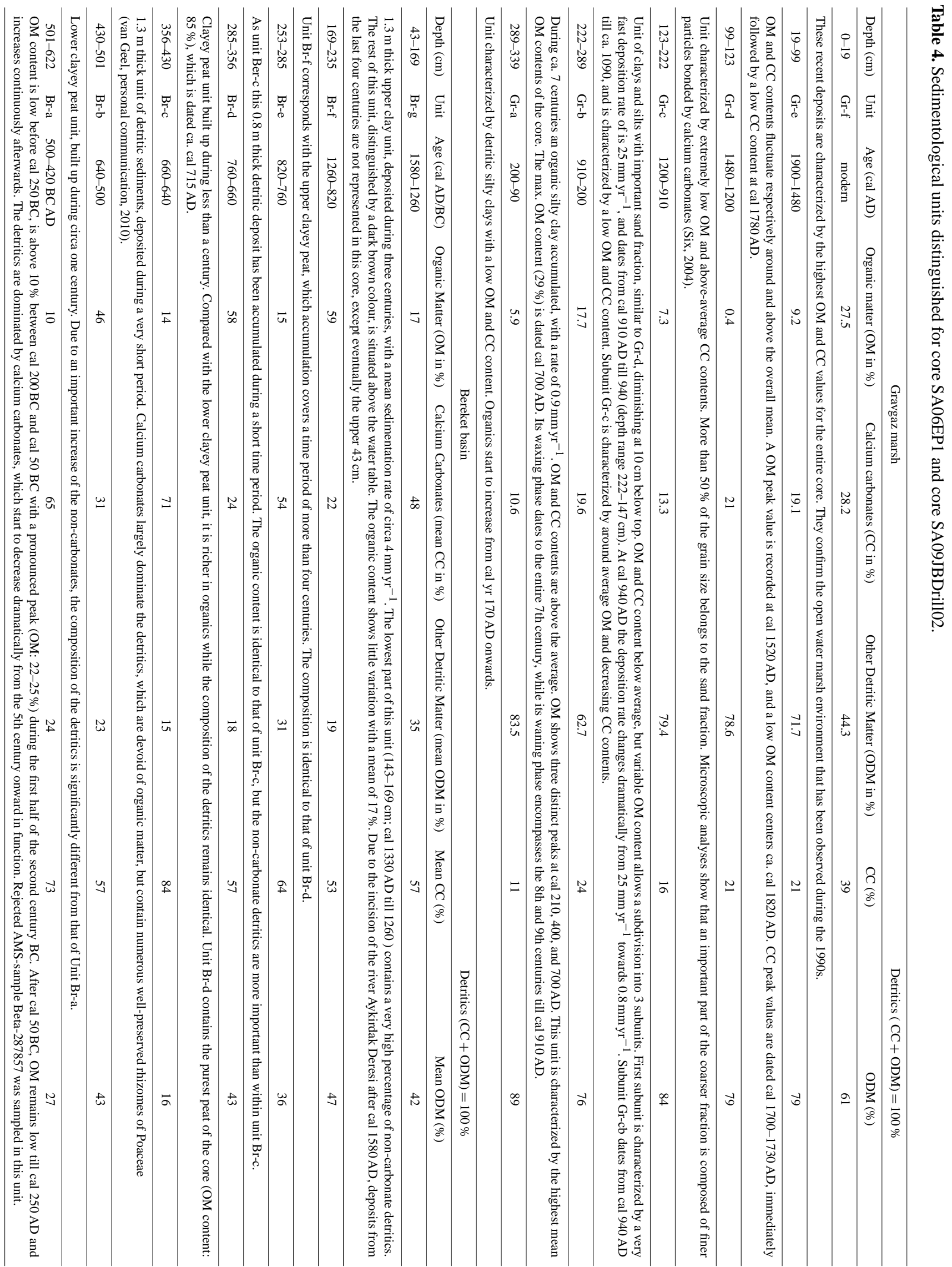


Table 5. Comparison of the well-dated age-depth curves of this core SA09JBDrill01 (Fig. 3) with core BKT1/2 (Fig. 2 of Kaniewski et al., 2007) evidence that deposits of an identical age are situated at greater depths in core SA09JBDrill01 compared to core BKT1/2.

\begin{tabular}{|c|c|c|c|c|c|}
\hline \multicolumn{2}{|c|}{ Core SA09JBDrill01 } & \multicolumn{3}{|c|}{ Cores BKT1/2 } & \multirow[b]{2}{*}{ Depth $(\mathrm{cm})$} \\
\hline Code & Age (cal yr BP) & Depth $(\mathrm{cm})$ & Code & Age (cal yr BP) & \\
\hline Beta- 287853 & $310 \times 40 \mathrm{BP}$ & 43 & & & \\
\hline Beta-287855 & $760 \times 40 \mathrm{BP}$ & 170 & & & \\
\hline Beta-287854 & $950 \times 40 \mathrm{BP}$ & 207 & & & \\
\hline Beta-295432 & $1190 \times 30 \mathrm{BP}$ & 234 & & & \\
\hline Beta-280822 & $1190 \times 40 \mathrm{BP}$ & 238 & & & \\
\hline Beta-295434 & $1220 \times 30 \mathrm{BP}$ & 270 & & & \\
\hline Beta-295433 & $1210 \times 30 \mathrm{BP}$ & 283 & & & \\
\hline Beta-274769 & $1350 \times 40 \mathrm{BP}$ & 331 & & & \\
\hline Beta-274770 & $1380 \times 40 \mathrm{BP}$ & 361 & Beta-223548 & $1390 \times 60 \mathrm{BP}$ & $\begin{array}{l}157 \\
\text { Depth incision at } \\
1380 \times 40 \text { BP: } 204 \mathrm{~cm}\end{array}$ \\
\hline Beta-280824 & $1410 \times 40 \mathrm{BP}$ & 463 & & & \\
\hline Beta-295437 & $1500 \times 30 \mathrm{BP}$ & 493 & & & \\
\hline Beta-280823 & $1610 \times 40 \mathrm{BP}$ & 507 & Beta-210929 & $1580 \times 40 \mathrm{BP}$ & $\begin{array}{l}197.5 \\
\text { Depth incision at } \\
1600 \times 40 \text { BP: } 309.5 \mathrm{~cm}\end{array}$ \\
\hline \multirow[t]{6}{*}{ Beta-295436 } & $1740 \times 30 \mathrm{BP}$ & 525 & Beta-210926 & $1710 \times 40 \mathrm{BP}$ & $\begin{array}{l}203.5 \\
\text { Depth incision at } \\
1730 \times 30 \text { BP: } 321.5 \mathrm{~cm}\end{array}$ \\
\hline & & & Beta-210927 & $1870 \times 40$ & 286 \\
\hline & & & Beta-193788 & $1970 \times 40 \mathrm{BP}$ & 470 \\
\hline & & & Beta-193789 & $2140 \times 40 \mathrm{BP}$ & 610 \\
\hline & & & Beta-210931 & $2370 \times 40 \mathrm{BP}$ & 729 \\
\hline & & & Beta-213851 & $2230 \times 40 \mathrm{BP}$ & 783 \\
\hline \multirow[t]{2}{*}{ Beta-287857 } & $2440 \times 40 \mathrm{BP}$ & 582 & & & \\
\hline & & & Beta-210930 & $3260 \times 190 \mathrm{BP}$ & 800 \\
\hline
\end{tabular}

and arboriculture, and the occurrence of secondary anthropogenic indicators. For Bereket, seven PDVPs were defined by the NJ analysis. Charcoal concentration is included in BKT7, associated with taxa indicative of fires (Ulex) and open vegetation (Asteraceae). The PDVP at the smallest ecological distance contains taxa indicative of pine forests $(P i$ $n u s)$. PDVPs associated with human occupation (BKT1) are located at a larger ecological distance.

The results of the CC analyses show that for both Gravgaz and Bereket, no significant correlation (larger than 0.5) existed between the relative charcoal concentration and any of the PDVPs. For the Bereket basin, there is a near-significant positive correlation at lag $=0$ of 0.41 for BKT7, while there is a non-significant positive correlation of 0.37 at a lag of -1 for BKT6. These results mirror the results of the NJ analysis. There is a further non-significant positive correlation of 0.44 at a lag of 1 for BKT4. Any other correlations nearing the significance threshold of 0.5 in both Gravgaz and Bereket occurred at a lag that was too large to be ecologically informative.

\subsubsection{CharAnalysis}

Fire episodes determined by the CharAnalysis software are displayed in Table 6, Figs. 6, 7, and Suppelement Figs. S1, and $\mathrm{S} 2$. In the Gravgaz marsh record, fire events have been identified to occur at ca. cal 1100, 1170, 1330, 1590 AD, and a single event in recent times, at ca. cal $1930 \mathrm{AD}$. For Bereket, fire activity is much more limited. Fire events have been identified to occur at ca. cal 320,610, 660, 740, and 790 AD. No signs of local fire damage in the form of burned leaves or seeds have been found.

When comparing the Gravgaz and Bereket charcoal records with the sediment records, it is clear that the two most recent fire events recorded for the Bereket basin immediately precede an important influx of CC-rich detritic sediments (unit Br-e), dated cal 760-820 AD. The pollen spectrum within this CC layer was comparable to that after and immediately prior to the sedimentation event. In the Gravgaz record, the nearly instant deposition of a $75 \mathrm{~cm}$ thick layer of sediment during the first half of the 10th century (cal 910 $940 \mathrm{AD}$ according to the chronology of Gravgaz) is immediately preceded by a peak in charcoal particles. This peak 

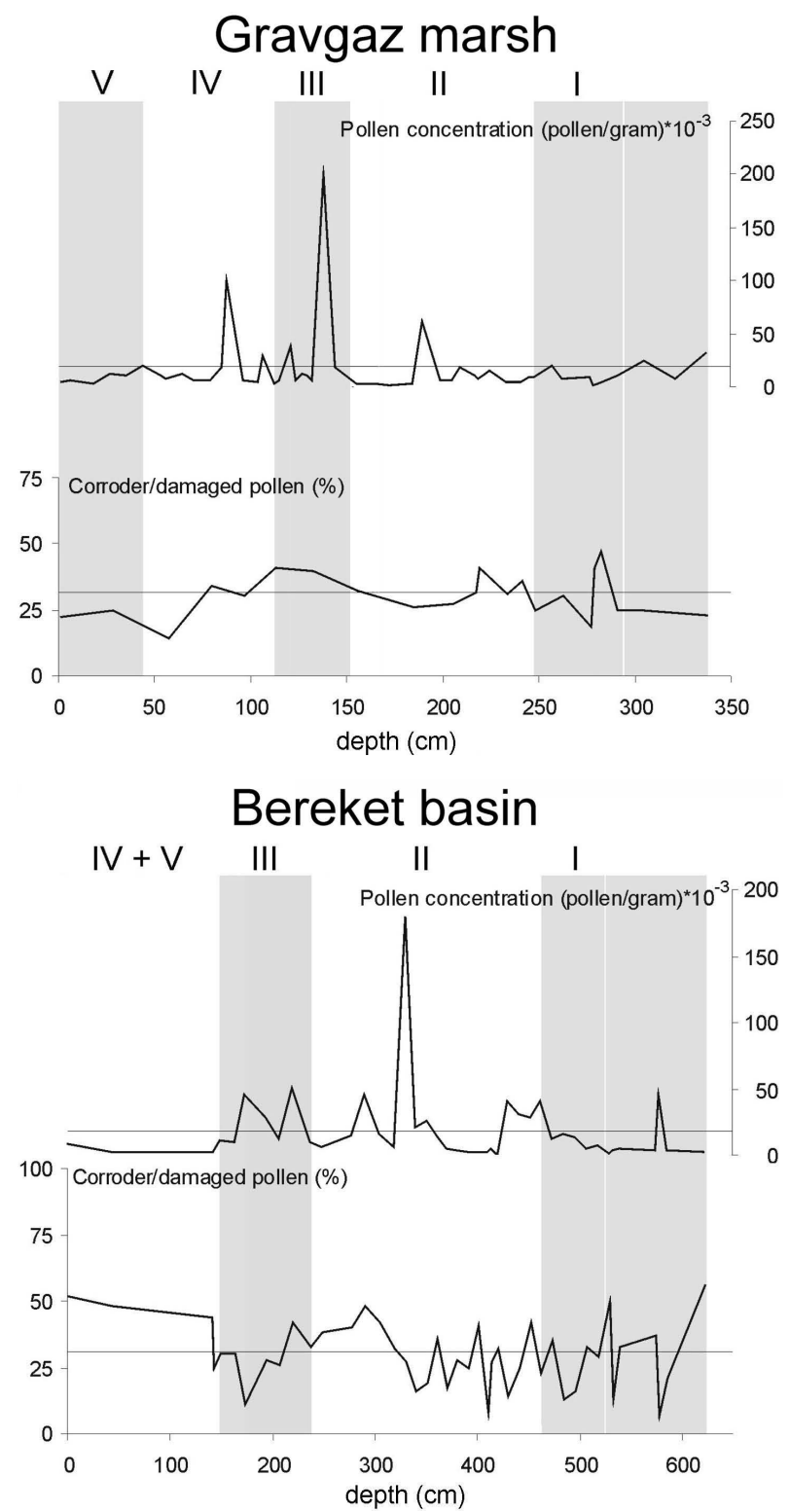

Fig. 4. Pollen concentration in pollen/gram, and pollen preservation expressed as the total percentage of the corroded, degraded, broken and crumpled pollen, for Gravgaz marsh (top) and Bereket basin (bottom). Vertical grey bars indicate a subdivision into bioclimatic periods (Bakker et al., 2012). I = Mid-3rd century - mid-7th century AD Wet Period and earlier. II = Mid-7th century - mid-10th century AD dry period. III = Mid-10th century - mid-13th century AD Wet Period. IV and V = Mid-13th century dry period until recent.

was not recognized as being significantly larger than the background charcoal signal by CharAnalysis.

\subsection{Vegetation dynamics}

Pollen percentages for the taxa used in the $\mathrm{NJ}$ analysis are grouped according to PDVP and drawn according to a depth scale in Fig. 7. Pollen percentage data for all pollen and
Table 6. List of dates (cal. BC/AD) per sediment core of fire events as determined by the CharAnalysis software.

\begin{tabular}{rrr}
\hline & $\begin{array}{r}\text { Date } \\
\text { (cal. BC/AD) }\end{array}$ & $\begin{array}{r}\text { Depth } \\
(\mathrm{cm})\end{array}$ \\
\hline & 1934 & 14 \\
Gravgaz Marsh & 1592 & 80 \\
& 1326 & 111 \\
& 1174 & 127 \\
& 1098 & 135 \\
\hline \multirow{3}{*}{ Bereket Basin } & 788 & 270 \\
& 736 & 302 \\
& 658 & 356 \\
& 606 & 474 \\
& 320 & 526 \\
\hline
\end{tabular}

non-pollen palynomorph taxa are displayed in diagrams S1 and S2. The discussion of vegetation changes will focus on general trends in the pollen data. Sediment data will be included if major changes in the local sediment data co-occur with changes in the regional pollen data. In order to facilitate presentation and discussion of the results, all sediment and pollen graphs are subdivided according to the climatic periods revealed by Bakker et al. (2012). The pollen-derived Climatic proxy of Bakker et al. (2012) is included in Fig. 8.

\subsubsection{Mid-3rd century - mid-7th century AD Wet Period}

In Gravgaz, cereal cultivation and arboriculture (Castanea, Juglans, Olea) remain present throughout this period, but a notable switch occurs during the second half of the 3rd century $\mathrm{AD}$, when cereal and olive cultivation disappear for a short period (2 samples, coinciding with a period of several decades) and then return, but at a lower abundance. During the late-3rd to the mid-7th century period, cultivated species in Gravgaz show a continuing, gradual decline in favour of moist deciduous woodland, (e.g. Populus, Platanus, Alnus) meadows (e.g. Sanguisorba, Plantago, Artemisia), and pine forest. Locally, the late-3rd century decline in agriculture cooccurs with relatively high values for Typha and Cyperaceae.

In Bereket, olive cultivation ends during the second half of the 3rd century $\mathrm{AD}$, while arboriculture on the whole (Fraxinus, Castanea) diminishes, first giving way to open, herbaceous steppe vegetation (Artemisia, Chenopodiaceae, Ericaceae), followed by grass-dominated steppe vegetation. Locally, the switch from agriculture to an open grassy steppe coincides with a distinct drop in Sporormiella, indicating dung, and increased presence of T200, a fungus growing on helophytes. The very high percentage values for Poaceae may partially be caused by the occurrence of reeds (e.g. Phragmites) on and around the sample site. The local environmental change may be related to the (re-)activation of a nearby spring. 

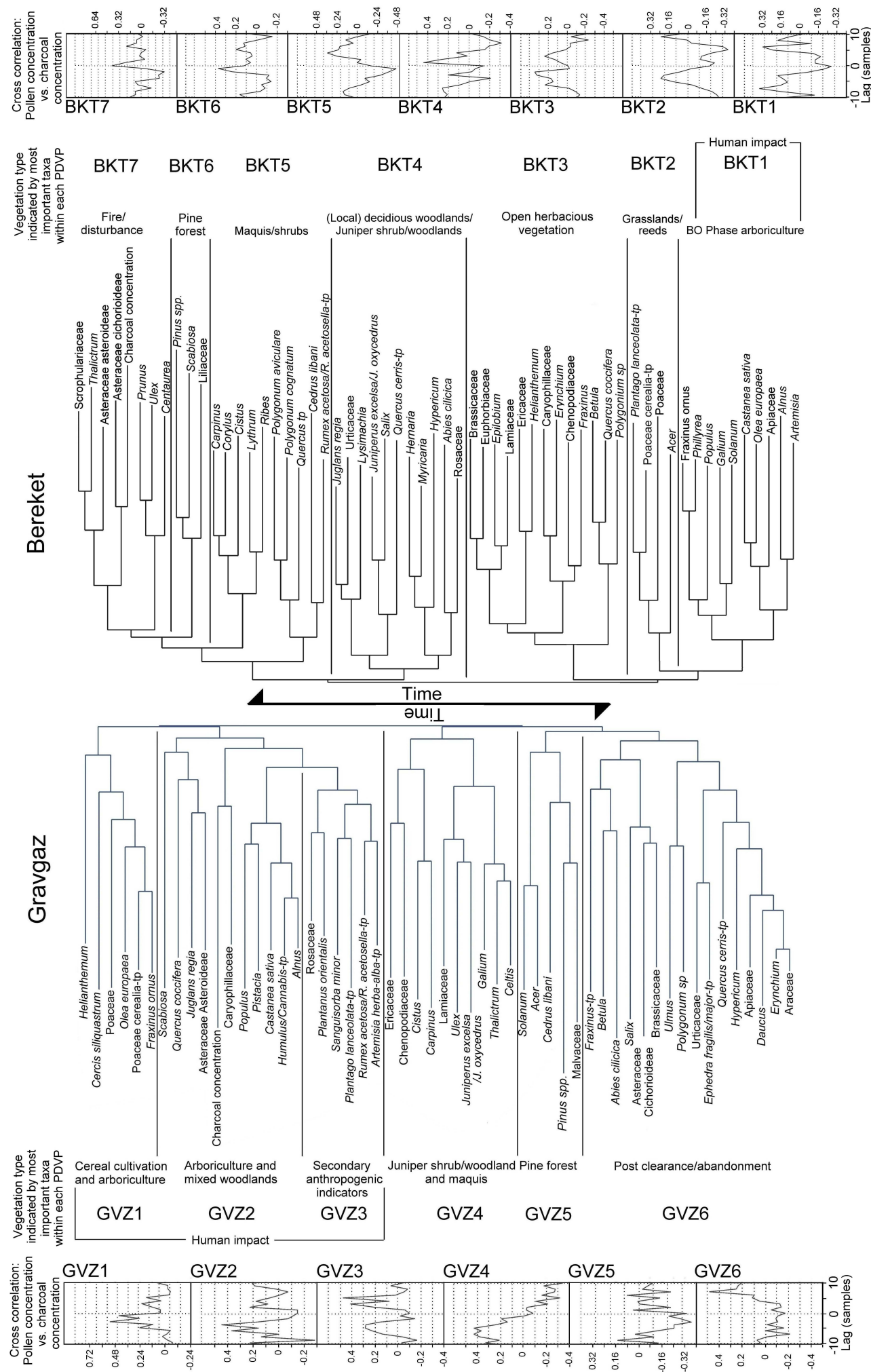

Fig. 5. Neighbour Joining tree diagrams for charcoal and pollen concentration data in the Bereket basin (top) and Gravgaz Marsh (bottom). Vegetation types associated with the most important pollen taxa in each PDVP are based on van Zeist et al. (1975), Bottema and Woldring (1990) Fontaine et al. (2007) and Kaniewski (2007a). Arrows indicate the order in which each PDVP reaches its maximum dominance in the pollen spectrum. On the far ends of the figure are Cross Correlograms displaying the correlation between each PDVP and relative charcoal concentration. 


\section{Gravgaz}

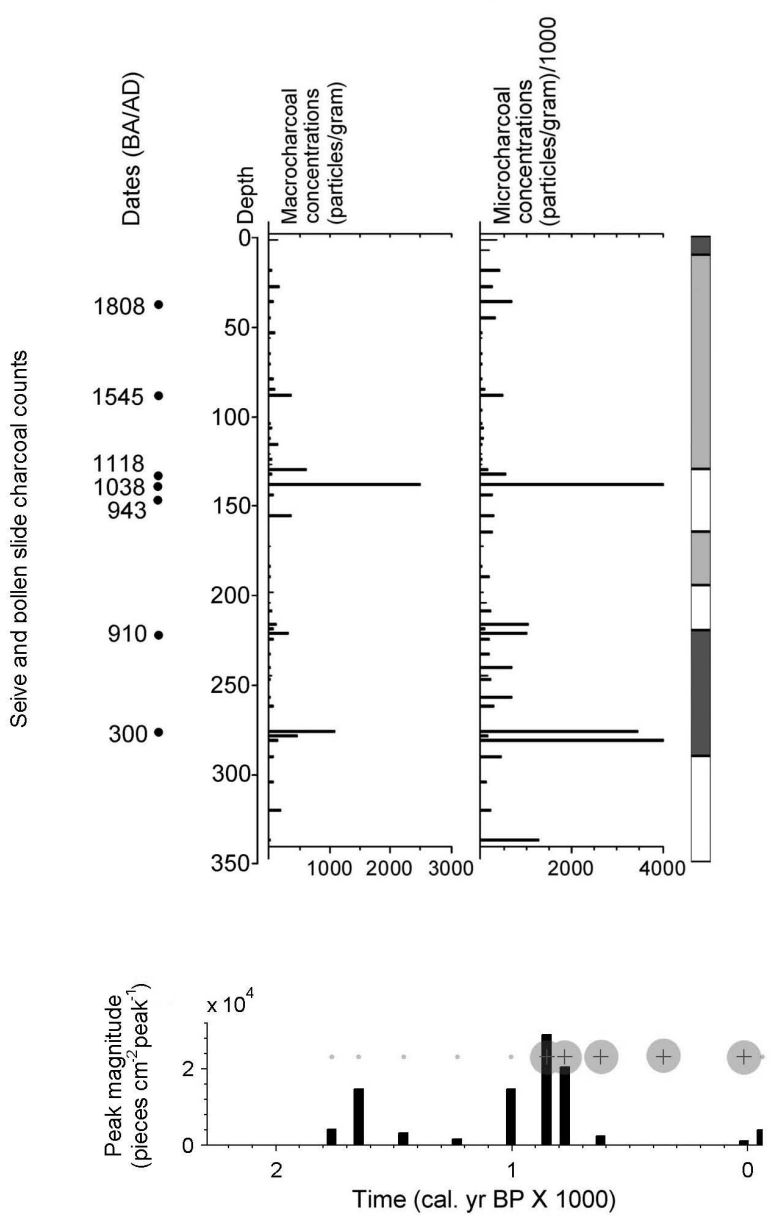

Bereket
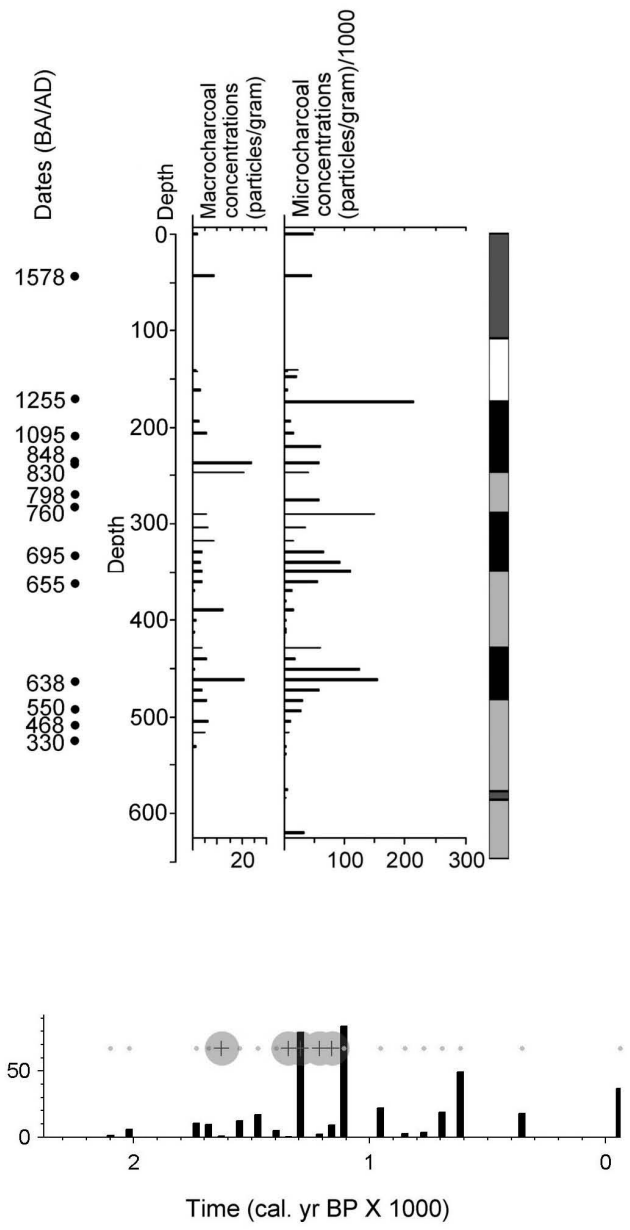

+ Significant CHAR peak (fire event)

Insignificant CHAR peak

- Peat

- Organic and carbonate rich clays

Sediments contaning non-carbonate detritics

Fig. 6. Top: peak magnitude and fire frequency as determined by CharAnalysis. Bottom: micro- and macroconcentrations and lithology.

\subsubsection{Mid-7th century - mid-10th century AD dry period}

In Gravgaz, olive and cereal cultivation end at ca. cal $640 \mathrm{AD}$, indicating the local end of the BO Phase. Subsequently, an open, dry shrub-steppe and maquis landscape appears, containing e.g. Caryophyllaceae, Cistus and increased values of Asteraceae Cichorioideae. The latter occasionally shows values of over $40 \%$. Pine pollen percentages fluctuate as a result of the occasional high percentage values for Asteraceae and fluctuating pollen production of deciduous trees, but remain important until the beginning of the 10th century AD.
The pollen signal within the rapidly deposited 7th century sediment unit $\mathrm{Br}-\mathrm{c}$ found in the Bereket core indicates the prevalence of open and dry vegetation (Apiaceae, Brassicaceae, Ericaceae, Asteraceae). Above this layer, several species which may indicate early stages of secondary afforestation of the valley floor (Quercus cerris, Salix) start to increase. A preliminary study of macro remains from this layer revealed the presence of leafs and buds from Salix as well as other leaf and wood material from deciduous trees and above ground remains of grasses (van Geel, personal communication, 2010), indicating the marsh was increasingly overgrown by grasses and riparian woodland developed on the sample site. The disappearance of aquatic plant species such as Lemna minor and Butomus umbellatus, 

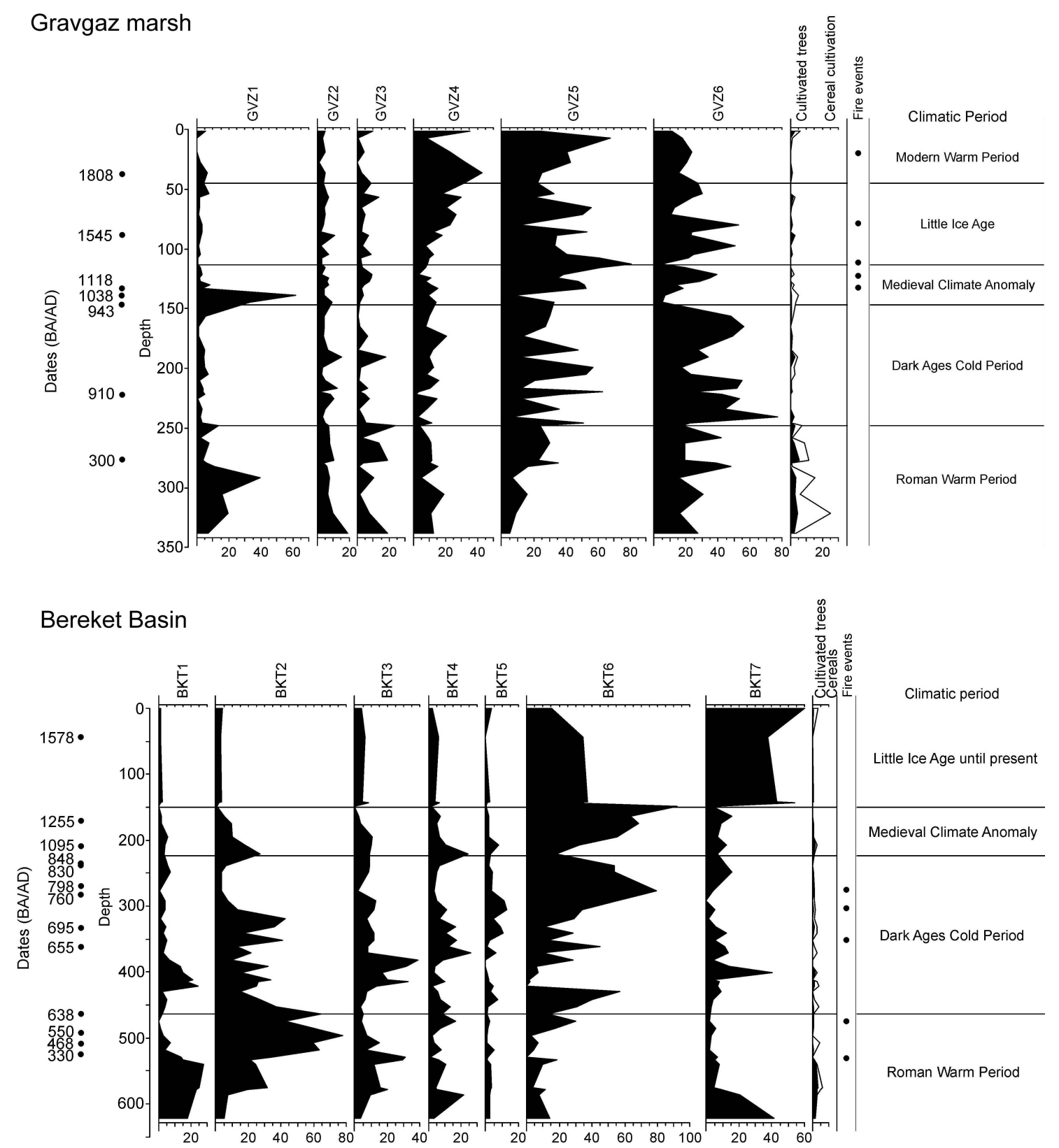

Fig. 7. Summary pollen diagrams displaying the total pollen percentage for each PDVP, and the fire events as detected by CharAnalysis, displayed along a depth axis.

and the appearance of clasterosporium, a fungus on sedges, further indicate continuing desiccation of the swamp. Pine forest increases in importance near the top of this zone, and eventually reaches pollen percentages of $80 \%$ within the second layer of $\mathrm{CC}$ dominated sediments (unit $\mathrm{Br}-\mathrm{e}$ ).

\subsubsection{Mid-10th century - mid-13th century AD Wet Period}

In Gravgaz, this zone is initially characterized by a resurgence in both secondary anthropogenic indicators (Plan- tago lanceolata, Sanguisorba minor, Castanea sativa, Fraxinus ornus), a decrease of dry steppe species (Apiaceae, Caryophyllaceae, Ericaceae), and indicators of grazing (Quercus coccifera). Limited cereal cultivation is present within this zone. It is interesting to note that the increase in moisture availability observed in the more regional tree and herbaceous pollen data from Gravgaz is not reflected in the more local aquatic/marsh pollen and NPP records.

A similar mid-10th century AD increase in anthropogenic indicators (o.a. Plantago lanceolata, Polygonum, Rumex), and riparian woodland taxa (Salix, deciduous oak, Populus) 
is visible in the Bereket pollen record. Signs of crop cultivation are less pronounced in Bereket than in Gravgaz. While cereals and Fraxinus ornus are present, they are not plentiful. Other cultivars are absent or near-absent. Increased percentage values for aquatic plant taxa (Myriophyllum, Alismataceae, Butomus) and Rivularia (a cyanobacteria living on water plants) indicates increasingly wet local conditions. In both records, the pollen spectra quickly become dominated by pine forests from the mid-12th century onward.

\subsubsection{Mid-13th century dry period until subrecent times}

In Gravgaz, signs of human impact continue to be absent, only returning in the topmost pollen samples. The pollen spectrum is dominated by Pine, while percentages for open, dry maquis vegetation increase from the late 17th century onwards. During the 18th century taxa indicating dry and open vegetation (e.g. Apiaceae, Lamiaceae, Ulex) decrease in favour of indicators of increased moisture availability $(Q$. cerris type, Urticaceae and Abies). A possible continued presence of pastoralism is indicated by the presence of coprophilous fungi.

For Bereket, only the part $143-169 \mathrm{~cm}$, dated cal 1260 $1330 \mathrm{AD}$, remains usable. It seems to indicate a continued dominance of pine forests, while signs of crop cultivation diminish. The post cal $1330 \mathrm{AD}$ sediment is characterized by low pollen concentration, a high percentage of corroded pollen and a very poor diversity of pollen in the pollen spectrum. The combination of all these factors indicates that these deposits in the Bereket core were located above the present water table, which had been lowered after the draining of the marsh, and are therefore not useful for pollen analyses. The usable part of the Bereket record mirrors the Gravgaz record, indicating high pine pollen percentages.

\section{Discussion}

\subsection{Sediment dynamics}

The OM values as well as the composition of the detritics are different for both sites (Table 4), illustrative of the differing local environments at both sites. The differences in composition are mainly caused by differences in sediment provenance. For both sites ophiolitic mélange, limestones and older colluvial deposits, all with different surface areas (Fig. 2), deliver mainly non-carbonates, but also calcium carbonates. These detritic CC are estimated below $10 \%$ for Gravgaz and below $20 \%$ for Bereket. The latter figure is based on data by Kaniewski et al. (2007) for the northern valley, which drains these substrates nearly exclusively.
Six (2004) revealed that the CC present in the sediments of the central part of the Gravgaz marsh may partially originate from the precipitation from source waters fed by an aquifer situated in the limestone substrate. The combination of above-the-mean values for both organics and $\mathrm{CC}$ in some lithological units at Gravgaz (Fig. 3 and Table 4) may be interpreted as the signature of evaporation processes in a local wetter environment where conservation of organics was possible. At Bereket, the strongly negative correlation between $\mathrm{OM}$ and $\mathrm{CC}$ content, very obvious in units $\mathrm{Br}-\mathrm{a}$ and $\mathrm{Br}-\mathrm{c}$, is caused by the presence of a long period characterized by the deposition of organic-rich material, interspersed by several short-term periods characterized by the deposition of CC dominated detritics. These short-term events are likely due to the influx of the eroded marl substrate from the western slopes and indicative of an open or absent vegetation on those locations. The possible role of authigenic CC at Bereket is unknown.

Local sediment dynamics more likely reflect changes in the local environment and need not be indicative of regional environmental changes. However, in Bereket and Gravgaz, two apparently synchronous shifts of a similar nature occur, suggesting that these reflect changes in the regional, rather than in the local environment. The first simultaneous shift in the local environments occurs during the second half of the mid-3rd century AD as a notable shift towards moister environmental conditions at both sites. At Gravgaz, this increase in moisture availability is indicated by the deposition of an organic clay (unit Gr-b) characterized by simultaneous increases for both OM and CC (Fig. 3). At Bereket, the organic content starts to increase from the 3rd century onward (unit $\mathrm{Br}-\mathrm{a})$, and eventually grades into a clayey peat deposit during the 6th century. The second simultaneous change is a shift towards a drier environment, occurring during the 13th century AD. At Gravgaz, the start of Unit Gr-d reflects a local drying trend and is dated cal 1190-1250 AD. At Bereket, the abrupt end of the accumulation of clayey peat at the close of unit Br-f, dated cal 1200-1280 AD, indicates a drastic decrease in local humidity as well.

This interpretation is supported by tree ring-based MayJune precipitation reconstructions for the altitudinal range 1700-2020 m a.s.l. in SW Anatolia. They provide for the period 1097-2000 AD a record of the May-June precipitation, for which the three most dry and the three most wet 70-yr periods are defined (Touchan et al., 2007). The driest 70-yr period, dendrochronologically dated 1195-1264, matches the shift towards a dryer local environment both at Gravgaz and Bereket.

During the intermediate millennium, both records show marked differences. At Bereket, the accumulation of a clayey peat continues from the 6th until the 13th century AD, interrupted only by two short-term accumulation periods, dated at cal 640-660 AD (unit Br-c), and at cal 760-820 AD (unit $\mathrm{Br}-\mathrm{e})$. At Gravgaz, local humidity, as expressed by the $\mathrm{OM}$ content, fluctuates. It steadily increases from the early-3rd 
century till cal 700 AD. During the 8th century AD, the trend is reversed and OM steadily decreases till ca. cal $900 \mathrm{AD}$. The onset of the drying trend at Gravgaz succeeds the regional onset of dry environmental conditions indicative of the Dark Ages Cold Period (DACP) indicated by Bakker et al. (2012) by ca. $50 \mathrm{yr}$, according to the available chronological data. This time lag may indicate that the marsh remained wet for a longer time. The very fast accumulation rate of $25 \mathrm{~mm} \mathrm{yr}^{-1}$, causing a 75 -cm-thick deposit (subunit Gr-ca) during the time period cal 910-940 AD, is the greatest disturbance in the Gravgaz basin since the 2nd century AD. Frechette and Meyer (2009) report that such a sedimentation event may be linked to fire activity. However, the peak in charcoal concentration was not significantly larger than the background charcoal signal according to the CHAR analysis. Additionally, the pollen data from Gravgaz and Bereket, as well as the statistical analyses of Bakker et al. (2012), imply that the landscape was very open and the environmental conditions very dry, making it possible that sedimentation events could happen even without the occurrence of a fire.

Following this depositional event, the deposition rate is reduced towards its normal level of ca. $1 \mathrm{~mm} \mathrm{yr}^{-1}$. OM and CC content remain low till ca. cal 1090 AD (unit Gr-c), suggesting drier conditions around the coring site. From ca. cal 1090-1200 AD, OM content reaches its normal level, suggesting that the local area becomes wetter again. This period covers the first wet 70-yr period 1098-1167 reconstructed from tree rings by Touchan et al. (2007).

The sediment deposited during the cal 1250-1440 AD period (Unit Gr-d) is characterized by very low OM and very high CC content. These characteristics are considered firm indications of a dominantly dry environment, with depletion of $\mathrm{OM}$ by oxidation and enrichment of $\mathrm{CC}$ by evaporation. The start of this period more or less coincides with a massive drop in OM content at Bereket, indicating a change in the bioclimate must have occurred in the wider area, rather than just a local phenomenon. This dry period is bordered by two of the three driest 70-yr periods detected by Touchan et al. (2007), and dated 1195-1264 (the driest) and 1434-1503.

The start of unit Gr-e, dated ca. cal $1490-1540 \mathrm{AD}$, is characterized by a pronounced increase in local humidity relative to the preceding unit. The timing of this period closely matches the occurrence of the most humid $70 \mathrm{yr}$ interval recognized by Touchan et al. (2007), which is dated 1518-1587 AD. From the 17th century onward, OM and CC content for Gravgaz mostly fluctuate around their mean value, suggesting a dominantly humid local environment. The 1591-1660 dry period of Touchan et al. (2007) is not observed in the sediment record. However, the sample with a higher-than-average OM content dated cal $1780 \mathrm{AD}$ corresponds with their 1743-1812 wet period. OM as well as CC values of the sediments dated to the 20th century (Unit Gr-f) are both very high and eventually comparable with the peak samples dated cal $700 \mathrm{AD}$.
In general, the Gravgaz record appears to have been more sensitive to environmental changes than the Bereket record. Changes in $\mathrm{OM}$ and $\mathrm{CC}$ content indeed show a remarkable correspondence with a tree ring-based reconstructed record of May-June precipitation in SW Anatolia (Touchan et al., 2007). The data from the Gravgaz record may therefore be indicative of multi-decennial environmental changes in the wider area, whereas the data from the Bereket basin may support or disprove notions concerning more local environmental change based on pollen or charcoal data.

\subsection{Vegetation dynamics}

The following section provides an interpretation of the changing interrelationships between climate, vegetation and human impact. Sediment data will be included if major changes in the local sediment data co-occur with changes in the regional pollen data. Individual fluctuations are ignored, as they may be the result of local or other short-term variations in pollen production. Changes in human impact (e.g. socio-economic/political changes) and climatic change are without doubt two of the most important driving forces behind vegetation/landscape change. At every important shift in the palynological and/or sedimentological record, it is important to avoid a deterministic approach by considering both climate as well as socio-economic/political change as possible driving forces behind a change in land use by the local population, and also consider the possibility that it need not be just one or the other factor which is responsible, but that more factors can act simultaneously. In the following section, the driving factor(s) of each important shift in land use, and the accompanying shifts in vegetation/sediment dynamics, are critically assessed. The climatic overview of Bakker et al. (2012), supported and refined by the dendroclimatological data of Touchan et al. (2007), provide a detailed overview of the timing and impact of climate change on the vegetation. For an overview of socioeconomic/political changes which may result in a shift in land use, we rely on the most recent insights concerning the archaeology and history of the city and territory of Sagalassos, as well as historical data concerning the wider region. Based on these assessments, the most likely scenario behind each change in land use and/or vegetation and sediment dynamics is proposed.

\subsubsection{Mid-3rd century - mid-7th century AD Wet Period}

The sedimentological and regional pollen data from both locations imply that the 3rd-7th century AD period, corresponding with the last part of the Roman Warm Period, is characterized by relatively moist conditions, theoretically beneficial to intensive agriculture in this summer-dry region. A similar change towards a more humid climate is observed throughout the Eastern Mediterranean (Hirschfeld, 2004; England et al., 2008; Jones et al., 2006; Sorell et 
al., 2007; Neumann et al., 2007a,) and beyond (von Rad et al., 1999).

The decrease in arboriculture and cereal cultivation at both sites, and shift towards herding/pastoralism, is unusual, as it is in contradiction with other Late Roman/Early Byzantine historical and palaeoecological records throughout the Eastern Mediterranean, which show BO Phase agriculture persisting into at least the 7th century AD (Bottema et al., 1986; Eastwood et al., 1998, 1999; England et al., 2008), or even an expansion of agriculture (Harrison, 2001; Leroy, 2010; Izdebski, 2012).

During the 3rd and 4th centuries AD, the Roman Empire suffered from an ongoing financial malaise, caused by the lack of a powerful government and the constant threat of invasion, which led to a strong inflation and devaluation (Mitchell, 2007). Furthermore, changes in the manner in which cities in the empire were governed resulted in a high financial burden on the local governing class. Financial troubles within Asia Minor, as well as in the Roman Empire as a whole, may have led to a decrease in the demand and a decrease in the value of (agricultural) goods produced within the territory, prompting a change in agricultural practices, or perhaps a partial breakdown of the agricultural system as land owners could no longer afford their activities. This too may have caused a decrease in agricultural activities within the study area. However, while the troubles of the Empire during the 3rd and 4th century $\mathrm{AD}$ resulted in a decrease in building activities in the city of Sagalassos (Vanhaverbeke and Waelkens, 2003; Waelkens and Poblome, 2011), the city and its territory remained relatively prosperous during the remainder of the Late Roman Imperial period (Poblome, 2006; Vanhaverbeke et al., 2007). At Bereket, the results of an intensive archaeological survey revealed that that the population of the habitational sites in the basin did not decrease during the late RWP (Kaptijn et al., 2012). Nevertheless, agriculture in Bereket and Gravgaz never recovered. This supports the notion that the decline in anthropogenic activity is likely not a result of the temporary decline of the Roman Empire as a whole.

As moisture availability increased from the mid-3rd century AD onwards, marshes and wetlands may have encroached upon arable land on the valley floors at Gravgaz and Bereket, limiting the possibilities for crop cultivation in the direct vicinity of the sample sites. At other, drier, valley floors within the study area, such a process need not have taken place. Even when wetlands do increase, this increase need not have been severe enough to drive away agricultural practices from a certain location. This is illustrated by the evidence for an increase in wetlands at the Ağlasun Çay valley presented in Fuller et al. (2012), while the pollen records of Vermoere (2004) indicate that human impact continued uninterrupted in that valley. The drop in anthropogenic activity recorded for Bereket and Gravgaz may be a localized response to a regional environmental change, rather than an indication of a large-scale change in agricultural practices.
The ongoing decline of the city of Sagalassos and its territory from the early Byzantine period, starting ca. 450/75 AD, onwards (Vanhaverbeke and Waelkens, 2003; Waelkens et al., 2006; Vanhaverbeke et al., 2004, 2007, 2011a) coincides with a continuing decline in primary and secondary anthropogenic activity in the pollen record. However, the section of the pollen record corresponding with this period (450$650 \mathrm{AD}$ ) is lacking in detail.

\subsubsection{Mid-7th century - mid-10th century AD dry period}

Bakker et al. (2012) indicate that the mid-7th century AD was characterized by an abrupt aridification of the environment, and suggested this dry period corresponded with the occurrence of the Dark Ages Cold Period in the region.

The present paper shows how the dry trend, indicated by the pollen signal, is supported by steadily decreasing OM content from the 8th century AD till ca. cal $900 \mathrm{AD}$ at Gravgaz, and reflected by the influx of CC-rich sediments in the Bereket basin ca. cal $650 \mathrm{AD}$ (unit Br-c). It may be assumed that the pollen signal obtained from this CC layer, and indicating dry, open steppe vegetation, partially originates from the vegetation on the marl substrate of the slopes west of the sample site. Although such a sedimentation event may result in the deposition of reworked older pollen, it is most likely that the pollen originating from the marls reflect the vegetation present at the moment of the erosion-deposition event, as pollen is not likely to preserve for prolonged periods in the drier sediments outside the wetland.

Vanhaverbeke et al. (2009) indicate that the number of settlements dropped drastically during this period. However, recent research results indicate that sites may have remained more numerous than previously assumed. Although further research is needed, recently discovered sites dating from this period are mostly small agricultural settlements, as opposed to the large nucleated settlements of the preceding period (Vanhaverbeke et al., 2011b). Their nature meant that their presence was not recorded by previous archaeological surveys. While the population decline may have been less extensive than previously thought, it remains clear that there was a drastic change in habitation practices within the territory at this time, evidenced by a change in the settlement pattern (Vanhaverbeke et al., 2009, 2011b), and a shift in agricultural practices from crop cultivation to livestock herding (Vermoere et al., 2007a, b; Bakker et al., 2012). A similar shift from crop cultivation to (semi-pastoral or pastoral) livestock herding during the 7th century $\mathrm{AD}$ is observed throughout the Eastern Mediterranean (England et al., 2008; Leroy et al., 2010; Bakker et al., 2011, 2012).

While the exact start and end dates for the various climatic periods may differ from location to location, many climatological records obtained throughout the Middle East seem to record a climatic deterioration in the form of a dry shift during the 7 th century, coinciding with the aforementioned 
shift in land use (e.g. Heim et al., 1997; Lückge et al., 2001; Jiang et al., 2002; Lamy et al., 2006; Migowski et al., 2006). Considering the similarity in the timing of both phenomena, and the impact that this dry trend is proven to have had on vegetation and sediment dynamics, the existence of a link between the two phenomena seems plausible. However, the role of Arab invaders must not be overlooked. After the Arab victory over the Byzantine fleet at Finike, near Antalya, known as "the Battle of the Masts" in $655 \mathrm{AD}$, Arab incursions into Pisidia became commonplace (Threadgold, 1997). Both the threat of Arab incursions, as well as a strong aridification of the climate would have resulted in a change in lifestyle of smaller farmers, from sedentary agriculture, to (semi)pastoralism.

The question whether these shifts in land use were driven by the climatic dry trend which occurred at the time, or a result of incursions of Arab forces during the mid-7th century $\mathrm{AD}$, has long been the subject of ongoing debate (Vanhaverbeke and Waelkens, 2003; Haldon, 2007; Neuman et al., 2007b; England et al., 2008; Leroy, 2010). It is considered most likely that a combination of both factors had caused the abandonment of farmland and settlements observed in Gravgaz and Bereket. Regardless of the exact origin of the observed changes in land use, the aridification of the climate would have driven the way the landscape responded to this shift in land use and how it developed over time afterwards.

In many records from the Eastern Mediterranean, the ending of the BO Phase is immediately followed by a sharp increase in Pinus pollen (Van Zeist et al., 1975; Bottema and Woldring, 1984; Roberts, 1990; Eastwood et al., 1998; Heim et al., 1997; England et al., 2008). Several high resolution pollen diagrams indicate that such an increase had indeed taken place at other locations (Neumann et al., 2007a, 2010), but the present paper reveals that this process of very fast reforestation is not necessarily the rule. The rise of pine forests at Gravgaz was initially subdued by the establishment of open, dry steppe vegetation. At Bereket, pine forest increased after the disappearance of crop cultivation, but percentages remained below the present-day background pine pollen signal (Bakker, unpublished data). The pollen signal within the layer rapidly deposited during the mid-7th century $(\mathrm{Br}-\mathrm{c})$, indicates the presence of open steppe vegetation near the sample site. Secondary succession, resulting in the establishment of pine forest, only takes place from the 8th century onward.

What caused the high pine percentages observed in some post-BO Phase pollen records is subject to ongoing debate. Some attribute it to fast reforestation by pine forests following a population decrease (Neumann et al., 2007b; Kaniewski at al., 2007b; England et al., 2008). Pines are early pioneers of abandoned farmland and can cope with dry environments (Zohary, 1995; Ne'eman et al., 2004; Neumann et al., 2007a). Others propose that high pine pollen percentages originated in open, overgrazed landscape where the local pollen signal was incapable of overpowering the pine pollen signal (Bot- tema and Woldring, 1995; Vermoere at al., 2000; Knipping et al., 2008). The pollen and lithological data of the present paper support the theory that a rise in pine pollen signals an increase in pine forest, rather than the presence of an open vegetation type as that type of vegetation appears separately in the pollen diagrams of Bereket and Gravgaz. Modern pollen samples collected by Vermoere (2004) and Bakker (2012) indicate that in the current landscape, pine pollen percentages of $70-90 \%$ will only be reached within a pine forest, on very high, exposed locations, locations largely devoid of plant cover, or locations where there is a large risk of poor pollen preservation. At other locations, pine pollen percentages will not be higher than ca. $40-60 \%$. Occasional peak values of Asteraceae pollen recorded in Gravgaz (Figs. 7 GVZ6, and Supplement Fig. S1) are likely the result of selective transportation and deposition caused by strong upward airflows in a warm, dry environment (Bottema and Woldring, 1984; Vermoere, 2004). The hypothesis that it is a sign of poor pollen preservation is rejected, as signs of poor pollen preservation and disturbance of the soil are absent.

Deciduous oak remained of relatively little importance after the end of the BO Phase, even though it was an important constituent of the primary climax vegetation prevalent prior to the onset of human impact in the study site. It may be that the overall dominance of pine, rather than (deciduous) oak, was a result of colluviation caused by (over)grazing, which may have further decreased the amount of fertile soils covering the hillsides and slopes. Dusar (2012) has shown how intensive land use caused an erosion process, removing most of the available fertile soils from the mountainsides within the territory of Sagalassos by the end of the Roman era. Deciduous oak, which is intolerant of calcareous soils, would be restricted to the fertile deposits on the basin floors, while Pine forests, which are more resistant to calcium rich soils, are able to extend their range (Roberts, 1990). However, many of the mountainsides in the study area have always been calcareous and it is impossible to determine how much more of the calcareous substrate in the study area had been exposed since the onset of human impact on the environment in the territory and how much the potential range of deciduous oak had decreased (if at all).

\subsubsection{Mid-10th century - mid-13th century AD Wet Period}

The period from the mid-10th to the late 13th century $\mathrm{AD}$ is palynologically generally characterized by relatively moist environmental conditions, suggested by Bakker et al. (2012) to be a regional expression of the Medieval Climate Anomaly.

The limited resurgence in anthropogenic activity from the mid-10th to the mid-12th century AD ( Figs. 7, 8, and Supplement Figs. S1 and S2), the onset of which coincides with the start of the MCA in the region, is not noted in earlier records from southwest Turkey (van Zeist, 1975; Bottema 
and Woldring, 1884), possibly due to their limited chronological framework. Primary and secondary anthropogenic indicators show a minimal increase compared to the preceding period, indicating that human activities remained focussed on livestock herding with limited cereal cultivation recorded for Gravgaz. It is notable that Olea cultivation remains absent during this period.

A similar resurgence in anthropogenic activity, with a notable absence of arboriculture, was recorded in Nar Lake, Central Turkey at ca. 950 AD (Eastwood et al., 2009). The lack of olive cultivation is attributed to the notion that during such unstable times as the Mid-Byzantine, it was not worth the effort to invest in such potentially vulnerable, timeintensive crops (England et al., 2008; Eastwood et al., 2009). By the 11th century $\mathrm{AD}$, measures aimed at protecting the rights of poor, small-scale farmers and prevent the acquisition of their lands by wealthy land owners were no longer upheld and more and more land was absorbed into large estates, resulting in a change in land use and inhabitation of these lands (Gregory, 2010). Such a process may also have resulted in the relative absence of crop cultivation in Gravgaz and Bereket during this period.

While coinciding with a climatic amelioration, the resurgence of agriculture from the 10th century onwards also coincides with a social and economical revival throughout the Byzantine Empire (Bintliff, 2000; Haldon, 2007; Knipping et al., 2008; Vionis et al., 2009a). This phenomenon is considered to be a result of 8th and 9th century AD administrative reforms (Gregory, 2010) and military victories rendering previously insecure territory to a more stable footing (England et al., 2008; Vionis et al., 2009b). However, various studies report that the first hints of recovery in the Byzantine countryside occurred no sooner than the 10th century (Vionis et al., 2009a; Eastwood et al., 2009; the present paper), coinciding exactly with the onset of the MCA in Europe and the Middle East (Bar-Matthews et al., 1999; Bond et al., 2001; Schilman et al., 2001, 2002; Gupta et al., 2003; Lamy et al., 2006; Kaniewski et al., 2010; Bakker et al., 2012). It is therefore tempting to consider that it may have been the amelioration of the climate which acted as a catalyst, further enabling the already ongoing expansion of agriculture into areas previously less attractive for agricultural practices, e.g. due to their remote location or less attractive (bio)climatic conditions.

The renewed anthropogenic impact in Gravgaz and Bereket ended mid-12th century AD and the region apparently becomes dominated by pine forest until the mid-16th century AD. A similar decline of agricultural practices, observed in the Nar lake pollen record, is linked to the arrival of the Selçuks in Cappadocia in ca. cal 1074 AD (Eastwood et al., 2009). The Selçuks started to dominate SW Turkey following the Battle of Malazgirt in 1071 AD and were in control of the territory of Sagalassos from 1204 AD, by the latest. This date is not unrealistically different from the mid12th century estimation for the disappearance of agriculture in Bereket and Gravgaz. Furthermore, the destruction of a fortified settlement on Alexander's Hill, near the site of the former city of Sagalassos can be considered contemporary (Poblome and Taloen, 2005; Vionis et al., 2010). There is no direct evidence supporting a link between the destruction of the site and the appearance of the Selçuks in the wider region. The construction of the hamam and kervansaray in the village of Ağlasun, located in the valley below Sagalassos, during the 13th century AD indicates a continued occupation of the area around the site during this period (Vanhaverbeke et al., 2009). This is also supported by the continuation of cereal cultivation near Ağlasun (Vermoere, 2004).

Rather than a result of the Selçuk conquest, the disappearance of any sign of agriculture in the palynological records of Bereket and Gravgaz may be the result of the political and economical deterioration of the Byzantine Empire during the Komnenoi (1082-1185 AD) and Angeloi (1185-1204 AD) dynasties in the years prior to the Selçuk conquest of the region. However, resurgence in the occupation of the fortified hamlets on the site of Sagalassos, and the construction of an additional fortification on the nearby Alexander's Hill, seems to be at odds with an apparent decline in agriculture. It may be that settlements in the territory shifted their agricultural practices towards more limited activities in the direct vicinity of the settlement in the face of external military threats, similar to the process which occurred during the 5th century. It may also be that shifts in land use were driven by further changes in the nature of land ownership. The mid-11th century AD saw the rise of the Pronoia system, with which land-owning nobility were granted full control over their territory in return for specific services to the crown, essentially creating semi-independent fiefdoms.

The palynological end of the agricultural period (or period of human impact) is dated ca. cal $1150 \mathrm{AD}$, and corresponds with the end of one of the wettest 70-yr intervals recorded by Touchan et al. (2007), occurring ca. 1098-1167 AD. However, the raw tree ring data of Touchan et al. (2007) indicate that the subsequent period remained relatively moist as well. Additionally, the pollen-derived bioclimatic proxy of Bakker et al. (2012) also indicates continued, relatively moist environmental conditions. A link between the disappearance of human impact and a shift to drier conditions seems less likely.

\subsubsection{Mid-13th century dry period until subrecent times}

Bakker et al. (2012) indicate that southwest Turkey underwent a climatic deterioration as reflected in the pollen data during the close of the 13th century, linking the start of this dry period to the start of the LIA. However, the lithological data from the Gravgaz core indicate local dry conditions only occurred earlier, from the early 13th century AD, while in Bereket, they occurred from the mid-13th century onward. These dates are in agreement with the precipitation data of Touchan et al. (2007), which indicate that one of the driest $70 \mathrm{yr}$ periods recorded in their tree ring data occurred at 
1195-1264 AD. While the start of this $70 \mathrm{yr}$ period was still relatively wet, it was characterized by much drier conditions from the early to mid-13th century $\mathrm{AD}$ onwards.

The delay in the pollen-derived bioclimatic record of Bakker et al. (2012) may be a result of the type of vegetation change upon which the observation was based. The shift in vegetation recorded for the early 14th century, and indicating a shift towards a drier bioclimate, is actually a change in the composition of tree species, rather than changes in the composition of herbaceous species (as with the $640 \mathrm{AD}$ dry shift). Tree species take a longer time to grow and produce enough pollen-producing offspring to be detected in the pollen signal and it is only to be expected that in this case the pollen data lags behind the sediment data.

The pollen data show that the regional environment remained relatively dry compared to the MCA, throughout the subsequent centuries, until ca. the 18th century AD, implying that the cold LIA was also characterized by relatively dry conditions in general, despite the occurrence of slightly wetter intervals within the LIA (such as indicated in Touchan et al., 2007).

If the proposed explanation for the delay in the pollen signal is correct, it would mean that the LIA started in SW Turkey with a period of extremely dry environmental conditions in the early to mid-13th century AD. This aridification event would have first been expressed in a change in the water availability at the marshes on the sample sites, resulting in the observed changes in the sediment records.

Pollen data from Gravgaz marsh indicate that the landscape, which at this time remained dominated by pine forest, became more open from the mid-16th century AD onward. Historical data indicate that the period from the late 13th century onward (after the Selçuks, and later the Ottomans, consolidated their territories) was characterized by increasingly peaceful conditions in Anatolia (Eastwood et al., 2009; Vanhaverbeke and Waelkens, 2003; Vryonis, 1971). Vanhaverbeke and Waelkens (2003) indicate how the Ottoman period saw a population increase in region during the 15th and 16th centuries. Increased pressure on the land and resulting reduced living standards eventually led to the Celali rebellions of the late 16th and early 17 th century. The resulting insecure situation may have led to a reduction of the population, a decline in agriculture and a corresponding increase in pastoralism (Vanhaverbeke and Waelkens, 2003). However, the 17th century also saw a major tax reform, which caused a shift in land ownership from Timars (a land granted by the Ottoman sultans as compensation for military service) to Çiftliks (a system of land management where powerful military officers started to claim land from the Sultan's holding, allowing them to pass the land onto their sons, creating large privately owned estates, the inhabitants of which were essentially used as serfs). The establishment of these may have impinged upon the hamlets and villages populated by independent farmers, forcing a shift from sedentary farming towards pastoralism (Jackson and Lampe, 1982; Keyder and Tabak, 1991).

Climatic change seems not to have played a role in the increase of pastoralism in the region. Before the 16th century $\mathrm{AD}$, sedimentological data indicate severe local drought conditions coinciding with regional dry conditions (Touchan et al., 2007). However, both the vegetation- as well as sediment data imply that, while local and regional environmental conditions did improve during the 16th century, they remained roughly comparable to those of the early DACP until the early 18th century AD. This is also reflected in the pollen data, which, apart from an increase in shrublands, indicate an increase in dry steppe, similar to that which developed after the mid-7th century AD. It is unknown whether the shortterm peak in precipitation around 1518-1587 AD, recorded by Touchan et al. (2007), had an influence on land use in the study region. Evidence for its occurrence does not exist in the pollen data. Only one sample in the sediment data of Gravgaz apparently coincides with this precipitation peak. While it does record an elevated OM value, this is not sufficient to establish whether it is the local manifestation of this precipitation peak.

The abundance of Pinus indicates that landscape openness was comparable to that observed for the 7th-10th centuries. The lack of an increase in coprophilous NPPs indicates that grazing did not take place near the sample site in Gravgaz. The pollen data indicate that the current landscape has a very recent origin. It is impossible to estimate how recent the very last samples of the pollen cores are, but historical evidence indicates that the present landscape is no older than ca. $100 \mathrm{yr}$. Vermoere (2004) indicates that it was the adaptation of agricultural machines and the establishment of a dense road network after the First World War, which boosted the expansion of agriculture, and resulted in the settlement of the (semi)nomadic populace of the region.

Unfortunately the most recent $500 \mathrm{yr}$ are only covered by the Gravgaz marsh pollen record. Preliminary studies into the relevant source area of pollen in the SW Taurus Mountains (Bakker, 2012) revealed that even for Pinus, changes in pollen percentages most likely only reflected changes in the vegetation within the basin in which a pollen core is located. Although the present paper indicates that the sediment and pollen record from the Gravgaz core is indicative of environmental changes in the wider region, the record only indicates how the landscape changed as a result of these environmental changes over a relatively limited area around the sample site. If there is indeed a link between the aforementioned shifts in human impact and the deforestation observed in the Gravgaz marsh, then this gradual deforestation may also have occurred elsewhere in the study area.

\subsection{Vegetation succession and fire activity}

The NJ ordination shows an overview of general vegetation change through time, from the crop cultivation that 
marked the BO Phase, to periods characterized by a relatively open landscape with an increasing cover of woody maquis species, and finally to a pine forest. This pattern resembles the Clementsian models of post-disturbance succession (Tomascelli, 1977). When human impact decreases or stops, the first stage of secondary succession of the vegetation is characterised by the dominance of herbaceous vegetation in the landscape, which is then replaced by woody shrub vegetation, eventually leading to a dominance of maquis or forest (Tomascelli, 1977). The final PDVP in both NJ tree diagrams represents the vegetation that becomes dominant in the pollen spectrum immediately after the clearing of pine forests.

Fire activity is seen as a major ecological factor, shaping the Mediterranean landscape with its mosaic-like pattern of regeneration and degradation stages (Walter, 1968; Naveh, 1975; Spanos et al., 2000; Gracia et al., 2002; Buhk et al., 2006). Fires can be seen as a natural part of the ecosystem in the Mediterranean basin and have occurred for millennia (Pausas et al., 2008).

The present data suggest that fire activity during the postBO Phase period is limited. The number of detected regional fire events is low (five in each basin; Table 6), and the lack of charcoal layers in the sediment and generally low concentrations of macroscopic charcoal particles, implies that no local fire activity occurred. Even though it is possible that CharAnalysis did not detect all fires that took place within the studied time frame, as the analysis was based on a discontinuous charcoal record, the results clearly show that extended fire periods, such as those recorded for the Bronze and Roman periods in Bereket by Kaniewski et al. (2008), did not occur. None of the fire events are recorded simultaneously at both basins, despite the distance between them being no more than ca. $11 \mathrm{~km}$, indicating their limited size and impact.

The lack of local and/or anthropogenic fire activity in Gravgaz and Bereket is in contrast with the situation during the BO Phase, for which Kaniewski et al. (2008) recorded a series of high intensity fire episodes that occurred between the 4th century BC and the 2nd century AD. These fires were succeeded by a simplification of the vegetation structure, favouring soil erosion, pastures and intensive cultivation in the Bereket basin. The fire history of Gravgaz marsh has never previously been researched.

Most of the fire events, as detected in the Gravgaz charcoal record by the CharAnalysis software, occur after the 12th century AD. Two fires coincide with the resurgence in human impact during the MCA, while one additional fire, occurring at ca. $1590 \mathrm{AD}$, coincides with a likely anthropogenic, deforestation phase. For Bereket, fire events seem to occur primarily at times when human impact is absent, during the 7th and 8th centuries AD. A limited human presence in the region can be assumed to occur throughout the postBO Phase period, despite the pollen data recording next to no anthropomorphic indicators. This human presence can be assumed to have been more focussed on livestock grazing, perhaps partially in the form of pastoralism (Vanhaverbeke and Waelkens, 2003; Vanhaverbeke et al., 2011a; Fuller et al., 2012). While fires could have been started by herdsmen, looking to enlarge their grazing grounds, one would expect a decrease in pine woodlands over a larger time period. Continuous grazing of the deforested landscape would lead to the encroachment of the opened landscape by shrub species (Asouti and Hather, 2001), while the further development of the landscape, towards a secondary pine forest, would be suspended. This phenomenon is observed for the 12th century fire events, and the $1590 \mathrm{AD}$ fire event in Gravgaz, and is suggested to occur during the $320 \mathrm{AD}$ fire event in Bereket. The pollen record implies that all other recorded fire events resemble natural fires in the wider vicinity of the sample sites. As stated before, it is possible that additional fire events were missed due to the limitations of the dataset used. However, the clustering of recorded fire events does provide an indication of when most fire activity is likely to have taken place in the region.

The timing of the fire events occurring in the vicinity of both sample sites is also reflected in the placement of charcoal within the NJ dendrograms of both Gravgaz and Bereket. In the NJ ordination of Gravgaz marsh, charcoal concentration is placed with human impact indicators. For Bereket, the connection between charcoal concentration and open steppe vegetation (Asteraceae, Centaurea), post-fire disturbance indicators (Ulex), and pine forest is also in accordance with the link between the occurrence of fire events and increased pine pollen percentages observed in the pollen records. As the NJ analyses essentially shows the link between charcoal deposited in individual fire events, and vegetation development which takes place over a longer time period, the NJ analyses support the notion that the fire events recorded by CharAnalyses may not give a complete fire history for both records, but do give a relatively accurate estimation of the period during which most fires occurred in the vicinity of both sample sites.

Vannière et al. (2008) suggest that climatic conditions were important for fire occurrence even under strongly humanised ecosystem conditions. Turner et al. (2008) concluded that Eastern Mediterranean regional fire activity was controlled by climatically-induced variations in biomass. The timing of those fire episodes in Gravgaz marsh and the Bereket basin that are centred on periods characterized by decreased human activity occur in periods characterized by relatively warm and wet, as well as cold and dry environmental conditions.

All fires not (suspected to be) linked with anthropogenic activity are related to an elevated abundance of pine forest. Pinus percentages at those instances were equal to, or higher than those found at present. Pine forests form the secondary climax vegetation in the region when human impact is absent and are able thrive during periods characterized by high, as well as low moisture availability (Fontaine et al., 


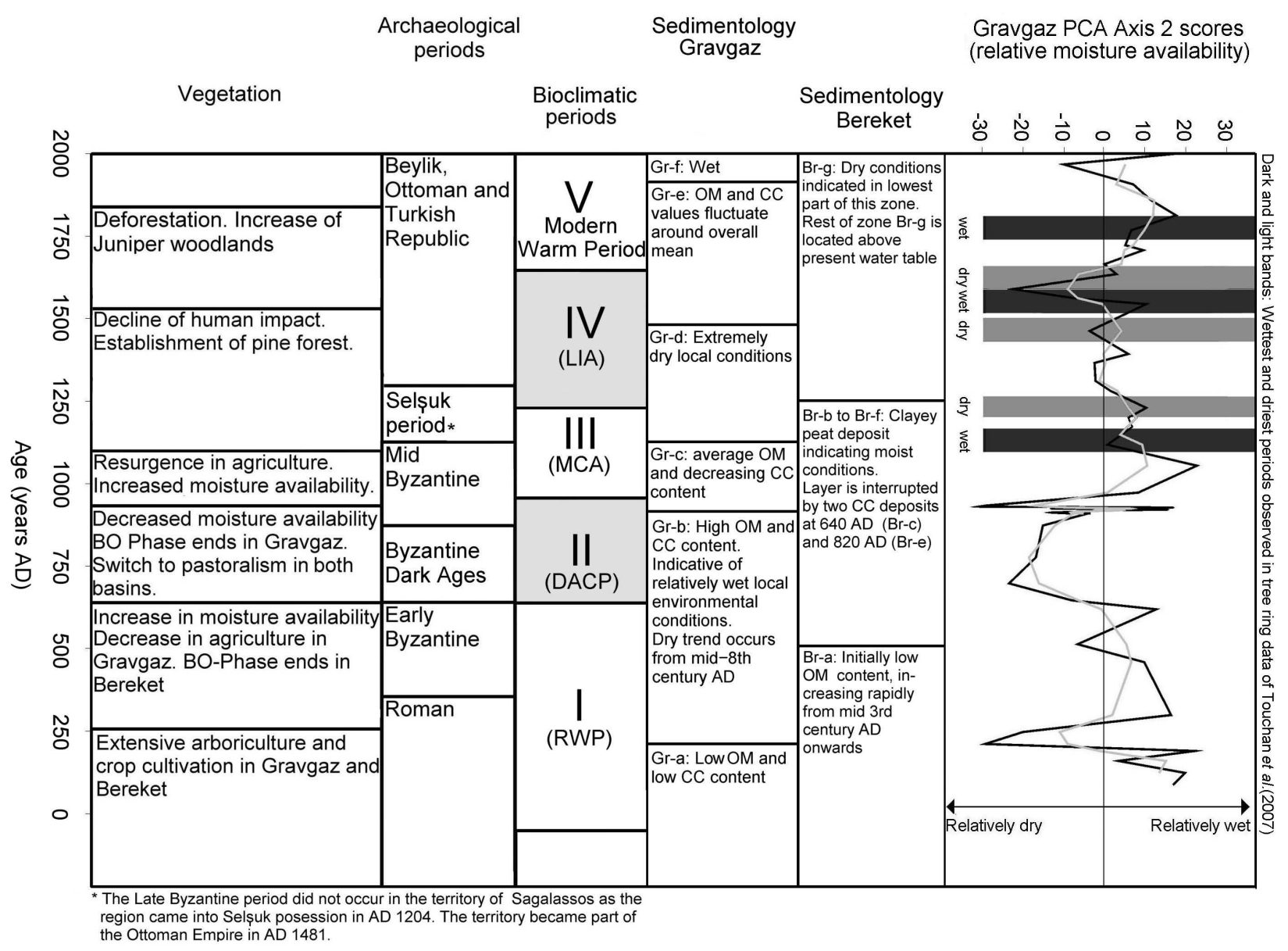

Fig. 8. An overview of the main changes in the vegetation and environmental conditions in the territory of Sagalassos, the main archaeological periods, the main climatic periods and the bioclimatic proxy for the territory of Sagalassos (Bakker et al., 2012) with the most extreme dry and wet periods detected by Touchan et al. (2007) superimposed. The subdivision into historical periods is based on Vanhaverbeke and Waelkens (2003).

2007), providing biomass which serves as fuel for (wild)fires, regardless of the climatic regime.

Pinus nigra is well adapted to cope with fire damage. It is a long-lived tree with a thick bark and can grow tall with only a few branches on the lower part of the trunk. This makes it very resistant to surface fires (Fulé et al., 2008; Pausas et al., 2008). Pinus brutia is a species characterized by a high post-fire resilience (Pausas et al., 2008), its serotinous cones able to protect seeds from fire damage. Thus Pinus brutia forests are able to quickly regenerate after fires. $P i$ nus brutia is nowadays restricted to the lower parts of the mountains, occurring below $1400 \mathrm{~m}$ a.s.l. However, its range may have extended higher than today during warm climatic phases such as the MCA and RWP. The present data therefore indicate that climate did not play an important role in driving the timing of fires during the post-BO Phase period, but rather anthropogenic activity and/or fuel availability in the form of the secondary climax vegetation developing after a decrease in human activity.

\section{Conclusions}

The sediment record of Gravgaz marsh provided a proxy of local moisture availability on a multi-centennial, and for some periods, on a multi-decennial scale. The integration of the pollen and sediment data of Gravgaz and Bereket, as well as the pollen-derived bioclimatic proxy of Bakker et al. (2012) and the tree ring data of Touchan et al. (2007) since $1097 \mathrm{AD}$, revealed that changes in local moisture availability actually represented changes in the regional climate. The sediment data managed to corroborate or improve the timing of the various bioclimatic periods observed by Bakker et al. (2012), while the synchronisms between the AMS-based time scales at Gravgaz and Bereket and the tree ring chronology of Touchan et al. (2007) strengthened the reliability of the chronological framework presented in the present paper, at least for the last millennium. At the same time, the similarities between the data presented in this study and the tree ring data of Touchan et al. (2007) imply that the latter study 
of springtime precipitation may actually be interpreted as an indication of year-round humidity.

The new data from the western Taurus Mountains, SW Turkey, shows how a climatic shift towards moister conditions in the 3rd century coincided with a shift in agricultural practices, away from intensive crop cultivation and towards pastoralism. The palaeoenvironmental data implies that an increase in moisture availability led to the extension of wetlands on the studied valley floors becoming too wet to use as arable land. This may have been a local phenomenon while agricultural practices in drier valleys need not have encountered problems, and may have even benefited from increased moisture availability.

A further, more severe shift towards pastoralism and population decrease during the mid-7th century could have been caused by the climatic deterioration, which led to relatively dry environmental conditions, although the role of Arab incursions into the region during the same period may also have played a role in driving the observed shift in land use.

The first indications of resurgence in agriculture in southwest Turkey occur during the mid-10th century. A similar phenomenon has been observed throughout Anatolia and it is suggested that increased moisture availability may have worked as a catalyst for the spread of human activity. Crop cultivation did not return to the levels of intensity witnessed during the BO Phase, while intensive arboriculture remained almost completely absent in the present record from southwest Turkey.

The abrupt drop in anthropogenic activity during the mid12th century is not related to a climatic deterioration. The climate remains wet until the mid-13th century. A link with Selçuk incursions is also not likely as archaeological records reveal no conclusive indications for Selçuk violence in the study area. It is more likely that the changes in vegetation are a localized response to changes in land use during the Mid Byzantine period. Increased landscape openness from the 16th century onwards may be linked to political unrest and changing landscape management during the Ottoman era.

The occurrence of fire events was not connected to specific climatic (relatively dry or wet) conditions, but rather to an increased human presence in the vicinity of Gravgaz marsh, and to fuel availability, most likely in the form of pine forests, in the vicinity of the Bereket basin. The general background charcoal concentration levels were in accordance with the results of the fire peak analysis, indicating that higher charcoal concentrations in the sediment were related to anthropogenic activity in the Gravgaz marsh record, while in Bereket, background charcoal concentrations were linked to open vegetation following fires/disturbances and closely linked to the presence of pine forests.

The pollen data reveals that the pattern revealed in older, lower resolution records, indicating a fast rise in Pinus pollen after the end of the Beyşehir Occupation Phase, is not necessarily accurate. The historical pollen data presented in this paper, in combination with modern pollen data, also imply that the notion of high Pinus pollen percentages indicating an open landscape incapable of countering the influx of pine pollen, is likely unrealistic.

As this is the first more detailed overview of vegetation change during the post-BO Phase period in SW Turkey, it is as of yet unclear how widespread the observed vegetation dynamics have been throughout the region. While climate change may be assumed to have had a regional impact, patterns of political, economical and social change may have differed between the various political entities in the region. Furthermore, the bioclimatic changes resulting from climatic change may be different at lower altitudes. It is vital that more palaeoecological records from southwest Turkey are studied in order to provide a detailed view of vegetation dynamics during this important but understudied period.

\section{Supplementary material related to this article is available online at: http://www.clim-past.net/9/57/2013/ cp-9-57-2013-supplement.pdf.}

Acknowledgements. This research was supported by the Belgian Programme on Interuniversity Poles of Attraction (IAP 6/22 and IAP 7/17) and the Research Fund of the K.U.Leuven (BOF-GOA 07/02 and GOA 13/04), next to project G.0421.06 of the Fund for Scientific Research, Flanders (FWO). The research of J. Bakker is financed by the Centre for Archaeological Sciences (Programme Financing, Special Research Fund of the K.U.Leuven). M. Waelkens is a beneficiary of a "Methusalem grant" from the Flemish Ministry for Science Policy. J. Poblome is a Francqui Research Professor. The Sagalassos Archaeological Research Project is thanked for providing administrative and logistical support. Philippe Muchez is thanked for his assistance in determining the lithology of core SA09JBDrill01. Bas van Geel is thanked for offering his expertise for the preliminary study of the macrobotanical remains. Eva Kaptijn, Rinse Willet, Adam Izdebski, and John Haldon are thanked for sharing their thoughts on the subject. Neil Roberts, Warren Eastwood, and the anonymous reviewer are thanked for their in-depth critical review of the discussion paper.

Edited by: D. Fleitmann

\section{References}

Asouti, E. and Hather, J.: Charcoal analysis and the reconstruction of ancient woodland vegetation in the Konya basin, south-central Anatolia, Turkey: results from the Neolithic site of Çatalhöyük East, Veg. Hist. Archaeobot., 10, 23-34, 2001.

Aussenac, G.: Ecology and ecophysiology of circum-mediterranean firs in the context of climate change, Annals For. Sci., 59, 233253, 2002.

Bakker, J.: Late Holocene Vegetation Dynamics in a Mountainous Environment in the territory of Sagalassos, Southwest Turkey (Late Roman till present), Dissertation, Katholieke Universiteit Leuven, Belgium, 239 pp., 2012. 
Bakker, J., Paulissen, E., Kaniewski, D., De Laet, V., Verstraeten, G., and Waelkens, M.: Man, vegetation and climate during the Holocene in the Territory of Sagalassos, Western Taurus mountains, SW Turkey, Veg. Hist. Archeobot., 21, 249-266, doi:10.1007/s00334-011-0312-4, 2011.

Bakker, J., Kaniewski, D., Verstraeten, G., De Laet, V., and Waelkens, M.: Numerically-derived evidence for late Holocene climate change and its impact on human presence in the southwest Taurus Mountains, Turkey, The Holocene, 22, 425-438, 2012.

Bar-Matthews, M., Ayalon, A., Kaufman, A., and Wasserburg G. J.: The Eastern Mediterranean paleoclimate as a reflection of regional events: Soreq cave, Israel, Earth Planet. Lett., 166, 85-95, 1999.

Baxter, M. J.: Exploratory Multivariate Analysis in Archaeology, Edinburgh University Press, Edinburgh, 1994.

Behre, K.-E.: Some reflections on anthropogenic indicators and the record of prehistoric occupation phases in pollen diagrams from the Near East, in: Man's role in the shaping of the eastern Mediterranean Landscape, edited by: Bottema, S., EntjesNieborg, G., and van Zeist, G., Balkema, Rotterdam, 219-229, 1990.

Beug, H. J.: Leitfaden der Pollenbestimmung für Mitteleuropa und angrenzende Gebiete, Verlag Dr. Friedrich Pfeil, Munchen, 2004.

Bintliff, J. L.: Reconstructing the Byzantine countryside: New approaches from mindscape archaeology, in: Byzanz als Raum, $\mathrm{Zu}$ Methoden und Inhalten der Historischen Geographie des Ostlichen Mittelmeerraumes, Austrian Academy of Sciences Press, Wien, 37-63, 2000

Bodnariuc, A., Bouchette, A., Deboudat, J. J., Otto, T., Fontugne, M., and Jalut, G.: Holocene vegetational history of the Apuseni mountains, central Romania, Quarternary Sci. Rev., 21, 14651488, 2002.

Bolle, H. J.: Mediterranean Climate: Variability and Trends, Springer Regional Climate Studies, Munich, 2003.

Bond, G., Showers, W., Cheseby, M., Lotti, R., Almasi, P., de Menocal, P., Priore, P., Cullen, H., Hajdas, I., and Bonani, G.: A Pervasive Millennial-scale Cycle in North Atlantic Holocene and Glacial Climates, Science, 278, 1257-1256, 1997.

Bond, G., Kromer, B., Beer, J., Muscheler, R., Evans, M. N., Showers, W., Hoffman, S., Lotti-Bond, R., Hajdas, I., and Bonani, G.: Persistent solar influence on North Atlantic climate during the Holocene, Sci., 294, 2130-2136, 2001.

Bottema, S.: Palynological investigations in Greece with special reference to pollen as an indicator of human activity, Palaeohistoria, 24, 257-289, 1982.

Bottema, S.: Pollen profile BOZOVA, Bozova Lake, Turkey, European Pollen Database (EPD), doi:10.1594/PANGAEA.711859, 2009a.

Bottema, S.: Pollen profile GOLBASI, Gölbasi Lake, Turkey, European Pollen Database (EPD), doi:10.1594/PANGAEA.711889, 2009b.

Bottema, S. and Woldring, H.: Late Quaternary vegetation and climate of Southwestern Turkey II, Palaeohist., 26, 123-149, 1984.

Bottema, S. and Woldring, H.: Anthropogenic indicators in the pollen record of the Eastern Mediterranean, in: Man's role in the shaping of the eastern Mediterranean Landscape, Balkema, Rotterdam, 231-265, 1990.
Bottema, S. and Woldring, H.: The environment of classical Sagalassos: a palynological investigation, in: Sagalassos III, Report on the fourth excavation campaign of 1993, Acta Archaeologica Lovaniensia Monographiae 7, Leuven University Press, Leuven, 327-340, 1995.

Bottema, S., Woldring, H., and Aytug, B.: Palynological investigations on the relation between prehistoric man and vegetation in Turkey: the Beyşehir Occupation Phase, in: Proceedings of the 5th OPTIMA Meeting, Istanbul, 315-328, 1986.

Bottema, S., Woldring, H., and Aytuğ, B.: Late Quaternary vegetation history of northern Turkey. Palaeohistoria, 35, 13-72, 1993.

Buck, C. E., Christen, J. A., and James, G. N.: BCal: an online Bayesian radiocarbon calibration tool, Internet Archaeology, 7, http://intarch.ac.uk/journal/issue7/buck_index.html (last access: 27 November 2011), 1999.

Buhk, C., Götzenberger, L., Wesche, K., Sànchez Gómez, P., and Hensenn, I.: Post-fire regeneration in a Mediterranean pine forest with historically low fire frequency, Acta Oecol., 30, 288-298, 2006.

Clark, J. S. and Pattersonn, W. A.: Background and local charcoal in sediments: scales of fire evidence in the paleorecord, in: Sediment Records of Biomass Burning and Global Change, edited by: Clark, J. S., Cachier, H., Goldammer, J. G., and Stocks, B. J., Springer, New York, 23-48, 1997.

Clark, J. S., Royall, P. D., and Chumbley, C.: The role of fire during climate change in an eastern deciduous forest at Devil's Bathtub, New York, Ecology, 77, 2148-2166, 1996.

Cullen, H. M. and deMenocal, P. B.: North-Atlantic influence on the Tigris-Euphrates stream-flow, Int. J. Climatol., 20, 155-168, 2000.

Cullen, H. M., Kaplan, A., Arkin, P. A., and Demenocal, P. B.: Impact of the North Atlantic Oscillation on the Middle Eastern Climate and Streamflow, Clim. Change, 55, 315-338, 2002.

Cushing, E. J.: Evidence for differential pollen preservation in late Quaternary sediments in Minnesota. Rev. Palaeobot. Palynol., 4, 87-101, 1967.

De Cupere, B., Thys, S., Van Neer, W., Ervynck, A., Corremans, M., and Waelkens, M.: Eagle Owl (Bubo bubo) Pellets from Roman Sagalassos (SW Turkey): Distinguishing the Prey Remains from Nest and Roost Sites, Intern. J. Osteoarchaeol., 19, 1-22, 2009.

Dusar, B., Verstraeten, G., Notebaert, B., and Bakker, J.: Holocene environmental change and its impact on sediment dynamics in the Eastern Mediterranean, Earth Sci. Rev., 108, 137-157, 2011.

Dusar, B., Verstraeten, G., D’Haen, K., Bakker, J., Kaptijn, E., and Waelkens, M.: Sensitivity of the Eastern Mediterranean geomorphic system towards environmental change during the late Holocene: a chronological perspective, J. Quaternary Sci., 27, 371-382, 2012.

Eastwood, W. J., Roberts, N., and Lamb, H. F.: Palaeoecological and archaeological evidence for human occupance in southwest Turkey: the Beyşehir occupation phase, Anatol. Stud. 48, 69-86, 1998.

Eastwood, W. J., Roberts, N., Lamb, H. F., and Tibby, J. C.: Holocene environmental change in southwest Turkey: a palaeoecological record of lake catchment-related changes, Quaternary Sci. Rev., 18, 671-95, 1999.

Eastwood, W. J., Leng, M., Roberts, N., and Davis, B.: Holocene climate change in the eastern Mediterra,ea, region: a comparison of stable isotope and pollen data from Lake Gölhisar, southwest 
Turkey, J. Quaternary Sci., 22, 327-341, 2007.

Eastwood, W. J., Gümüşçü, O., Yiğitbaşığlu, H., Haldon, J. F., and England, A.: Integrating Palaeoecological and ArchaeoHistorical records: Land use and Landscape change in Cappadocia (central Turkey) since late Antiquity, in: Archaeology of the countryside in medieval Anatolia, Nederlands Instituut voor het Nabije Oosten, Leiden, 45-69, 2009.

England, A., Warren, J., Eastwood, C., Roberts, N., Turner, R., and Haldon, J. F.: Historical landscape change in Cappadocia (central Turkey): a palaeoecological investigation of annually laminated sediments from Nar Lake, The Holocene, 18, 1229-1245, 2008.

Faegri, K. and Iversen, J.: Textbook of pollen analysis (4th Edn.), Blackburn Press, New Jersey, 1989.

Frechette, J. D. and Meyer, G. A.: Holocene fire-related alluvialfan deposition and climate in ponderosa pine and mixedconifer forests, Sacramento Mountains, New Mexico, USA, The Holocene, 19, 639-651, 2009.

Fulé, P. Z., Ribas, M., Gutiérrez, E., Vallejo, R., and Kaye, M. W.: Forest structure and fire history in an old Pinus nigra forest, eastern Spain, Forest Ecol. Manag., 255, 1234-1242, 2008.

Fuller, B., De Cupere, B., Marinova, E., Van Neer, W., Waelkens, M., and Richards, M.: Isotopic Reconstruction of Human Diet and Animal Husbandry Practices During the Classical- Hellenistic, Imerial and Byzantine Periods as Sagalassos, Turkey, Am. J. Phys. Anthropol., 149, 157-171, 2012.

Fontaine, M., Aerts, R., Özkan, K., Mert, A., Gülsoy, S., Süel, H., Waelkens, M., and Muys, B.: Elevation and exposition rather than soil types determine communities and site suitability in the Mediterranean mountain forests of southern Anatolia, Turkey, For. Ecol. Manag. 247, 18-25, 2007.

Gracia, M., Retana, J., and Roig, P.: Mid-term successional patterns after fire of mixed pine-oak forests in NE Spain, Acta Oecol., 23, 405-415, 2002.

Gregory, T. E.: A history of Byzantium. John Wiley and Sons, Chichester, 2010.

Grimm, E. C.: TILIA and TILIA.GRAPH, Illinois State Museum, Springfield, 1991.

Gupta, A. K., Anderson, D. M., and Overpeck, J. P.: Abrupt changes in the Asian southwest monsoon during the Holocene and their links to the North Atlantic Ocean, Nat., 421, 354-357, 2003.

Hajar. L., Haïdar-Boustani, M., Khater, C., and Cheddadi, R.: Environmental changes in Lebanon during the Holocene: Man vs. climate impacts, J. Arid. Environ., 74, 746-755, 2010.

Haldon, J.: "Cappadocia Will Be Given Over to Ruin and Become a Desert". Environmental Evidence for Historically-attested Events in the 7th-10th Centuries', in: Byzantina Mediterranea. Festschrift für Johannes Koder, zum 65 Geburtstag. Böhlau, Vienna, 215-230, 2007.

Harrison, R. M.: Mountain and Plain: from the Lycian Coast to the Phrygian Plateau in the Late Roman and Early Byzantine Period, University of Michigan Press, Ann Arbor, 2001.

Heim, C., Nowaczyk, N. R., Negendank, J. F. W., Leroy, S. A. G., and Ben-Avraham, Z.: Near East desertification: evidence from the Dead Sea, Naturwissenschaften, 84, 398-401, 1997.

Higuera, P. E., Peters, M. E., Brubaker, L. B., and Gavin, D. G.: Understanding the origin and analysis of sediment charcoal records with a simulation model, Quarternary Sci. Rev., 26, 1790-1809, 2007.
Higuera, P. E., Gavin, D. G., Bartlein, P. J., and Hallett, D. J.: Peak detection in sediment-charcoal records: impacts of alternative data analysis methods on fire-history interpretations, Int. J. Wildland Fire, 19, 996-1014, 2010.

Hirschfeld, Y.: A climatic change in the Early Byzantine period? Some archaeological evidence, Palest. Explor. Q., 136, 133-149, 2004.

Heim, C., Nowaczyk, N. R., Negendank, J. F. W., Leroy, S. A. G., and Ben-Avraham, Z.: Near East desertification: evidence from the Dead Sea. Naturwiss., 84, 398-401, 1997.

Huhmann, M., Kremenetski, K. V., Hiller, A., and Brückner, H.: Late Quaternary landscape ecolution of the upper Dnister valley, western Ukraine, Palaeogeog. Palaeoclim. Palaeoecol., 209, 51$71,2004$.

Izdebski, A.: Why did agriculture flourish in the late antique east? The role of climate fluctuations in the development and contraction of agriculture in Asia Minor and the Middle East from the 4th till the 7th c. AD, Millenium, Jahrbuch zu Kultur und Geschichte des ersten Jahrtausends n. Chr, 8, 291-312, 2012.

Jackson, M. R. and Lampe, J. R.: Balkan Economic History, 15501950: From Imperial Borderlands to Developing Nations, Indiana University Press, Bloomington, 1982.

Jiang, J., Mendelssohn, R., Schwing, F., and Fraedrich, K.: Coherency detection of multiscale abrupt changes in historic Nile flood levels, Geophys. Res. Lett. 29, 112-115, 2002.

Jones, M. D., Roberts, C. N., Leng, M. J., and Türkeş, M.: A highresolution Late Holocene lake isotope from Turkey and links to North Atlantic and monsoon climate, Geology, 34, 361-364, 2006.

Kaniewski, D., De Laet, V., Paulissen, E., and Waelkens, M.: Longterm effects of human impact on mountenous ecosystems, western Taurus Mountains, Turkey, J. Biogeogr., 34, 1975-1997, 2007a.

Kaniewski, D., Paulissen, E., De Laet, V., Dossche, K., and Waelkens, M.: A high-resolution Late Holocene landscape ecological history inferred from an intramontane basin in the Western Taurus Mountains, Turkey, Quaternary Sci. Rev., 26, 22012218, 2007b.

Kaniewski, D., Paulissen, E., De Laet, V., and Waelkens, M.: Late Holocene fire impact and post-fire regeneration from the Bereket basin, Taurus Mountains, southwest Turkey, Quaternary Res., 70, 228-239, 2008.

Kaniewski, D., Paulissen, E., Van Campo, E., Weiss, H., Otto, T., Bretschneider, J., and Van Lerberghe, K.: Late second-early first millennium BC abrupt climate changes in coastal Syria and their possible significance for the history of the Eastern Mediterranean, Quaternary Res., 74, 207-215, 2010.

Kaniewski, D., Van Campo, E., Paulissen, E., Weiss, H., Otto, T., Bakker, J., Rossignol, I., and Van Lerberghe, K.: Medieval coastal Syrian vegetation patterns in the principality of Antioch, The Holocene, 22, 251-262, 2011a.

Kaniewski, D., Van Campo, E., Paulissen, E., Weiss, H., Bakker, J., Rossinol, I., and Van Lerberghe, K.: The medieval climate anomaly and the Little Ice Age in coastal Syria inferred from pollen-derived palaeoclimatic patterns, Global Planet. Change, 78, 178-187, 2011b.

Kaptijn, E., Vanhaverbeke, H., Poblome, J., and Waelkens, M.: Societal change in the Bereket Valley in the Imperial period: a pottery perspective. Results from the Sagalassos Territorial 
Archaeological Survey 2008 (SW Turkey), J. Rom. Arch., submitted, 2012.

Keyder, Ç. and Tabak, F.: Landholding and commercial agriculture in the Middle East, State University of New York Press, Albany, 1991.

Knipping, M., Müllenhoff, M., and Brückner, H.: Human induced landscape changes around Bafa Gölü (western Turkey), Veg. Hist. Archaeobot., 17, 365-380, 2008.

Kuhry, P.: The palaeoecology of a treed bog in western boreal Canada: a study based on microfossils, macrofossils and physico-chemical properties, Rev. Palaeobot. Palynol., 96, 183224, 1997.

LaFontaine, C. V. and Bryson, R. A.: Airstream Regions of North Africa and the Mediterranean, J. Climate, 3, 366-372, 1990.

Lamy, F., Arz, H. W., Bond, G. C., Bahr, A., and Pätzold, J.: Multicentennial-scale hydrological changes in the Black Sea and northern Red Sea during the Holocene and the Arctic/North Atlantic Oscillation, Paleoceanogr., 21, PA1008, doi:10.1029/2005PA001184, 2006.

Leroy, S. A. G.: Pollen analysis of core DS7-1SC (Dead Sea) showing intertwined effects of climatic change and human activities in the Late Holocene, J. Archaeol. Sci., 37, 306-316, 2010.

Leroy, S. A. G., Kazanc1, N., illeri, Ö., Kibar, M., Emre, O., McGee, E., and Griffiths, H. I.: Abrupt environmental changes within a late Holocene lacustrine sequence south of the Marmara Sea (Lake Manyas, N-W Turkey): possible links with seismic events, Mar. Geol., 1-2, 531-552, 2002.

Luterbacher, J., Xoplaki, E., Küttel, M., Rutishauser, T., Pauling, A., and Wanner, H.: Mediterranean past climate variability, CLIVAR Exchanges, 11, 6-7, 2006a.

Luterbacher, J., Xoplaki, E., Casty, C., Wanner, H., Pauling, A., Küttel, M., Rutishauser, T., Brönnimann, S., Fischer, E., Fleitmann, D., González-Rouco, F. J., García-Herrera, R., Barriendos, M., Rodrigo, F., Gonzales-Hidalgo, J. C., Saz, M. A., Gimeno, L., Ribera, P., Brunet, M., Paeth, H., Rimbu, N., Felis, T., Jacobeit, J., Dünkeloh, A., Zorita, E., Guiot, J., Türkes, M., Alcoforado, M. J., Trigo, R., Wheeler, D., Tett, S., Mann, M. E., Touchan, R., Shindell, D. T., Silenzi, S., Montagna, P., Camuffo, D., Mariotti, A., Nanni, T., Brunetti, M., Maugeri, M., Zerefos, C., De Zolt, S., Lionello, P., Nunes, M. F., Rath, V., Beltrami, H., Garnier, E., and Le Roy Ladurie, E.: Mediterranean Climate Variability Over the Last Centuries: A Review. Dev. Earth. Environ. Sci., 4, 27-184, 2006b.

Luterbacher, J., Koenig, S. J., Francke, J., van der Schrier, G., Zorita, E., Moberg, A., Jacobeit, J., Della-Marta, P. M., Küttel, M., Xoplaki, E., Wheeler, D., Rutishauser, T., Stössel, M., Wanner, H., Brázdil, R., Doprovolný, P., Camuffo, D., Bertolin, V., van Engelen, A., Gonzales-Rouco, F. J., Wilson; R., Pfister, C., Limanówka, D., Nordli, Ø., Leijonhufvud, L., Döderberg, J., Allan, R., Barriendos, M., Glasier, R., Riemann, D., Hao, Z., and Zerefos, C. S.: Circulation dynamics and its influence on European and Mediterranean January-April climate over the past half millennium: results and insights from instrumental data, documentary evidence and coupled climate models, Clim. Change, 101, 201-234, 2009.

Luterbacher, J., García-Herrera, R., Akcer-On, S., Allan, R., Alvarez-Castro, M.-C., Benito, G., Booth, J., Büntgen, U., Cagatay, N., Colombaroli, D., Davis, B., Esper, J., Felis, T., Fleitmann, D., Frank, D., Gallego, D., Garcia-Bustamante, E., Glaser,
R., Gonzalez-Rouco, F. J., Goosse, H., Kiefer, T., Macklin, M. G., Manning, S. W., Montagna, P., Newman, L. Power, M. J., Rath, V., Ribera, P., Riemann, D., Roberts, N., Sicre, M. -A., Silenzi, S., Tinner, W., Tzedakis, P. C., Valero-Garcés, B., van der Schrier, G., Vannière, B., Vogt, S., Wanner, H., Werner, J. P., Willett, G., Williams, M, H., Xoplaki, E., Zerefos, C. S., and Zorita, E.: A review of 2000 years of Paleoclimatic evidence in the Mediterranean, in: The climate of the Mediterranean region: From the past to the future, edited by: Lionello, P., Elsevier Science Publishing Co Inc, New York, 2012.

Lückge, A., Doose-Rolinski, H., Khan, A. A., Schulz, H., and Von Rad, U.: Monsoonal variability in the northeastern Arabian Sea during the past 5000 years: geochemical evidence from laminated sediments, Paleogeogr. Paleoclim. Paleoecol., 167, 273286, 2001.

Magyari, E. K, Chapman, J. C., Gaydarska, B., Marinova, E., Deli, T., Huntley, J. P., Allen, J. R. M., and Huntley, B. The "oriental" composition of the Balkan flora: evidence of presence on the Thracian Plain during the Weichselian late-glacial, J. Biogeogr. ,35, 865-883, 2007.

McNeil, J. R.: The mountains of the Mediterranean world: an environmental history, Cambridge University Press, Cambridge, 1992.

Migowski, C., Stein, M., Prasad, S., Negendank, J. F. W., and Agnon, A.: Holocene climate variability and cultural evolution in the Near East from the Dead Sea sedimentary record, Quaternary Res., 66, 421-431, 2006.

Mitchell, S.: A History of the Later Roman Empire AD 284-641: The Transformation of the Ancient World, Blackwells, Oxford, 2007.

Moore, P. D., Webb, J. A., and Collinson, M. E.: Pollen Analysis. Blackwell Scientific Publications, Oxford, 1991.

Naveh, Z.: The evolutionary significance of fire in the Mediterranean region, Plant Ecol., 2, 199-208, 1975.

Ne'eman, G., Goubitz, S., and Nathan, R.: Reproductive traits of Pinus halepensis in the light of fire-a critical review, Plant Ecol., 171, 69-79, 2004.

Neumann, F., Schölzel, C., Litt, T., Hense, A., and Mordechai, S.: Holocene vegetation and climate history of the northern Golan heights (Near East), Veget. Hist. Archaeobot., 16, 329346, 2007a.

Neumann, F. H., Kagan, E. J., Schwab, M. J., and Stein, M.: Palynology, sedimentology and palaeoecology of the late Holocene Dead Sea, Quaternary Sci. Rev., 26, 1476-1498, 2007 b.

Neumann, F. H., Kagan, E. J., Leroy, S. A. G., and Baruch, U.: Vegetation history and climate fluctuations on a transect along the Dead Sea west shore and their impact on past societies over the last 3500 years, J. Arid Env., 74, 756-764, 2010.

Oğuz, D.: Remaining tree species from the indigenous vegetation of Ankara, Landscape Urban Plan., 68, 371-388, 2004.

Oldfield, F., Asioli, A., Accorsi, C. A., Mercuri, A. M., Juggins, S., Langone, L., Rolph, T., Trincardi, F., Wolff, G., Viglotti, L., Frignani, M., van der Post, K., and Branch, N.: A high resolution late Holocene palaeo environmental record from the central Adriatic Sea, Quaternary Sci. Rev., 22, 319-342, 2003.

Pals, J. P., van Geel, B., and Delfos, A.: Paleoecological studies in the Klokkeweel bog near Hoogkarspel (Noord Holland), Rev. Palaeobot. Palynol., 30, 371-418, 1980. 
Pausas, J. G., Llovet, J., Rodrigo, A., and Vallejo, R.: Are wildfires a disaster in the Mediterranean basin? A review, Int. J. Wildland Fire, 17, 713-723, 2008.

Poblome, J.: Mixed Feelings on Greece and Asia Minor in the Third Century AD, in: Old Pottery in a New Century. Innovating Perspectives on Roman Pottery Studies. Atti del Convegno Internazionale di Studi, Catania, 22-24 Aprile 2004. Catania, S.N., 2006.

Poblome, J. and Talloen, P.: "Report on the 2003 excavation and restoration campaign at Sagalassos, 6: sondages on Alexander's Hill”, KazıSonuçlarıToplantısı, 26, 428-429, 2005.

Power, M. J., Whitlock, C., Bartlein, P., and Stevens, P. R.: Fire and vegetation history during the last 3800 years in northwestern Montana, Geomorphology, 75, 420-436, 2006.

Reille, M.: Pollen et spores d'Europe et d'Afrique du nord, Laboratoire de Botanique historique et Palynologie, Marseille, 1992.

Reimer, P. J., Baillie, M. G. L., Bard, E., Bayliss, A., Beck, J. W., Blackwell, P. G., Bronk Ramsey, C., Buck, C. E., Burr, G. S., Edwards, R. L., Friedrich, M., Grootes, P. M., Guilderson, T. P., Hajdas, I., Heaton, T. J., Hogg, A. G., Hughen, K. A., Kaiser, K. F., Kromer, B., McCormac, F. G., Manning, S. W., Reimer, R. W., Richards, D. A., Southon, J. R., Talamo, S., Turney, C. S. M., van der Plicht, J., and Weyhenmeyer, C. E.: INTCAL 09 and MARINE09 radiocarbon age calibration curves, 0-50,000 years Cal BP, Radiocarbon, 51, 1111-1150, 2009.

Riehl, S. and Marinova, E.: Mid-Holocene vegetation change in the Troad (W Anatolia): man-made or natural?, Veget. Hist. Archaeobot., 17, 297-312, 2008.

Roberts, N.: Human induced landscape change in south and southwest Turkey during the later Holocene, in: Man's role in the shaping of the Eastern Mediterranean landscape, Balkema, Rotterdam, 53-67, 1990.

Roberts, N., Reed, J. M., Leng, H. J., Kuzucuoğlu, C., Fontugne, M., Bertaux, J., Woldring, H., Bottema, S., Black, S., Hunt, E., and Karabiyıkoğlu, M.: The tempo of Holocene climatic change in the eastern Mediterranean region: new high-resolution craterlake sediment data from central Turkey, Holocene, 11, 721-736, 2001.

Saitou, N. and Nei, M.: The neighbor-joining method: a new method for reconstructing phylogenetic trees, Mol. Biol. Evol., 4, 206225, 1987.

Schilman, B., Bar-Mattthews, M., Almogi-Labin, A., and Luz, B.: Global climate instability reflected by eastern Mediterranean marine records during the late Holocene, Palaeogeog. Palaeoclim. Palaeoecol., 176, 157-176, 2001.

Schilman, B., Ayalon, A., Bar-Matthews, M., Kagan, E. J., and Almogi-Labin, A.: Sea-Land paleoclimate correlation in the Eastern Mediterranean region during the Late Holocene, Isr. J. Earth Sci., 51, 181-190, 2002.

Six, S.: Holocene geomorphological evolution of the territory of Sagalassos. Contribution to the palaeo-environmental reconstruction of Southwest Turkey. Dissertation, Katholieke Universiteit Leuven, Belgium, 539 pp., 2004.

Six, S., Paulissen, E., Van Tuyne, T., Lambrechts, J., Vermoere, M., De Laet, V., and Waelkens, M.: Late Holocene sediment characteristics and sediment accumulation in the marsh of Gravgaz: evidence for abrupt environmental changes, in: Sagalassos VI. Geo- and Bioarchaeology at Sagalassos and in its territory, Leuven University Press, Leuven, 189-210, 2008.
Sorell, P., Popescu, S.-M., Klotz, S., Suc, J.-P., and Oberhänsli, H.: Climate variability in the Aral Sea basin (Central Asia) during the late Holocene based on vegetation changes, Quaternary Res., 67, 357-370, 2007.

Spanos, I. A., Daskalakou, E. N., and Thanos, C. A.: Postfire, natural regeneration of Pinus brutia forests in Thasos island, Greece, Acta Oecol., 21, 13-20, 2000.

Threadgold, W.: A history of the Byzantine State and Society, Stanford University Press, Stanford, 1997.

Tomaselli, R.: Degradation of the mediterranean maquis, AMBIO, 6, 356-362, 1977.

Touchan, R., Akkemik, Û., Hughes, M. K., and Erkan, N.: May-June precipitation reconstruction of southwestern Anatolia, Turkey during the last 900 years from tree rings, Quaternary Res., 68, 196-202, 2007.

Triantaphyllou, M. V., Ziveri, P., Gogou, A., Marino, G., Lykousis, V., Bouloubassi, I., Emeis, K.-C., Kouli, K., Dimiza, M., RosellMelé, A., Papanikolaou, M., Katsouras, G., and Nunez, N.: Late Glacial-Holocene climate variability at the south-eastern margin of the Aegean Sea. Mar. Geol., 266, 182-197, 2009.

Turner, R., Roberts, N., and Jones, M. D.: Climatic pacing of Mediterranean fire histories from lake sedimentary microcharcoal, Global Planet. Change, 63, 317-324, 2008.

Unal, Y., Kindap, T., and Karaca, M.: Redefining the climate zones of Turkey using cluster analysis, Int. J. Climatol., 23, 1045-1055, 2003.

van der Wiel, A. M.: A palaeoecological study of a section from the foot of the Hazendonk remains, Rev. Palaeobot. Palynol., 38, 35-90, 1983.

van Geel, B. and Aptroot, A.: Fossil ascomycetes in Quaternary deposits, Nova Hedwigia, 82, 313-329, 2006.

van Geel, B., Bohncke, S. J. P., and Dee, H.: A palaeoecological study of an upper late Glacial and Holocene sequence from "De Borchert", The Netherlands, Rev. Palaeobot. Palynol., 31, 367448, 1981.

van Geel, B., Hallewas, D. P., and Pals, J. P.: A late Holocene deposit under the Westfriese Zeedijk near Enkhuizen (Prov. of NHolland, the Netherlands): Palaeoecological and archaeological aspects, Rev. Palaeobot. Palynol., 38, 269-335, 1983.

van Geel, B., Buurman, J., Brinkkemper, O., Schelvis, J., Aptroot, A., van Reenen, G., and Hakbijl, T.: Environmental reconstruction of a Roman Period settlement site in Uitgeest (The Netherlands), with special reference to coprophilous fungi, J. Archaeol. Sci., 30, 873-883, 2003.

Vanhaverbeke, H. and Waelkens, M.: The chora of Sagalassos. The evolution of the settlement pattern from Prehistoric until recent times, Studies in Eastern Mediterranean Archaeology-SEMA 5, Brepols Publishers n.v., Turnhout, 2003.

Vanhaverbeke, H., Martens, F., Waelkens, M., and Poblome, J.: Late antiquity in the territory of Sagalassos (Pisidia, SW Turkey), in: Late antique archaeology 2 . Recent research on the late antique countryside, Brill, Leiden, 247-279, 2004.

Vanhaverbeke, H., Martens, F., and Waelkens, M.: Another view on Late Antiquity: Sagalassos (SW Anatolia), its Suburbium and its Countryside in Late Antiquity, in: The transition to late Antiquity on the Danube and beyond. Oxford university press, Oxford, 611-648, 2007.

Vanhaverbeke, H., Vionis, A. K., Poblome, J., and Waelkens, M.: What happened after the 7th century AD? A different Perspective 
on Post-Roman Rural Anatolia, in: Archaeology of the Countryside in Medieval Anatolia, Leiden, Nederlands Instituut voor het Nabije Oosten, 2009.

Vanhaverbeke, H., Degryse, P., De Cupere, B., Van Neer, W., Waelkens, M., and Muchez, P.: Urban-rural integration at ancient Sagalassos (SW Turkey). Archaeological, archaeozoological and geochemical evidence, Archaeofauna, 20, 73-83, 2011a.

Vanhaverbeke, H., Waelkens, M., Jacobs, I., Lefere, M., Kaptijn, E., and Poblome, J.: The 2008 and 2009 survey season in the territory of Sagalassos. Arastirma Sonuçlari Toplantisi (28), Arastirma Sonuçlari Toplantisi. Istanbul, 24-28 May 2010, 139-153, 2011 b.

Vannière, B., Colombaroli, D., Chapron, E., Leroux, A., Tinner, W., and Magny, M.: Climate versus human-driven fire regimes in Mediterranean landscapes: the Holocene record of Lago dell'Accesa (Tuscany, Italy), Quaternary Sci. Rev., 27, 11811196, 2008.

van Zeist, W., Woldring, H., and Stapert, D.: Late Quaternary vegetation and climate of southwestern Turkey, Palaeohist., 17, 55143, 1975.

Vermoere, M.: Holocene Vegetation History in the Territory of Sagalassos (Southwest Turkey) A Palynological Approach. Studies, in: Eastern Mediterranean Archaeology-SEMA 6, Brepols Publishers n.v., Turnhout, 1-347, 2004.

Vermoere, M., Smets, E., Waelkens, M., Vanhaverbeke, H., Librecht, I., Paulissen, E., and Vanhecke, L.: Late Holocene environmental change and the record of human impact at Gravgaz near Sagalassos, Southwest Turkey, J. Archaeol. Sci., 27, 571$595,2000$.

Vermoere, M., Van Thuyne, T., Six, S., Vanhecke, L., Waelkens, M., Paulissen, E., and Smets, E.: Late Holocene local vegetation dynamics in the marsh of Gravgaz (southwest Turkey), J. Paleolimnol., 27, 429-451, 2002a.

Vermoere, M., Bottema, S., Vanhecke, L., Waelkens, M., Paulissen, E., and Smets, E.: Palynological evidence for late-Holocene human occupation recorded in two wetlands in SW Turkey, The Holocene, 12, 569-584, 2002b.

Vionis, A. K., Poblome, J., and Waelkens, M.: Ceramic continuity and Daily Life in Medieval Sagalassos, sw Anatolia (ca. 6501250 AD), in: Archaeology of the Countryside in Medieval Anatolia. PIHANS 113. Leiden 2009: Netherlands Institute for the Near East, 191-213, 2009a.

Vionis, A. K., Poblome, J., and Waelkens, M.: The hidden material culture of the Dark Ages. Early Medieval ceramics at Sagalassos (Turkey): New evidence (ca AD 650-800), Anatolian Studies, 59, 147-165, 2009b.

Vionis, A. K., Poblome, J., De Cupere, B., and Waelkens, M.: A middle-late Byzantine pottery assemblage from Sagalassos, Typo-chronology and sociocultural interpretation, Hesperia, 79, 423-464, 2010.
Von Rad, U., Schaaf, M., Michels, K. H., Schulz, H., Berger, W. H., and Sirocko, F.: A 5000-yr record of climate change in the varved sediments from the oxygen minimum zone off Pakistan, northeastern Arabian Sea, Quaternary Res., 51, 39-53, 1999.

Vryonis, S.: The decline of Medieval Hellenism in Asie Minor and the Process of Islamization from the Eleventh through the Fifteenth Century, University of California Press, Berkley, 1971.

Waelkens, M.: Sagalassos. History and Archaeology. Sagalassos I, First General Report on the Survey (1986-1989) and Excavations (1990-1991), in: Acta Archaeologica Lovaniensia Monographiae 5, edited by: Waelkens, M., Leuven University Press, Leuven, 1993.

Waelkens, M.: City in the sky: excavating a classical metropolis in the mountains of southern Turkey, Archaeol., 57, 36-39, 2004.

Waelkens, M. and Poblome, J.: Sagalassos, city of dreams, Openbaar Kunstbezit in Vlaanderen, Gent, 2011.

Waelkens, M., Paulissen, E., Vermoere, M., Degryse, P., Celis, D., Schroyen, K., DeCupere, B., Librecht, I., Nackaerts, K., Vanhaverbeke, H., Viaene, W., Muchez, P., Ottenburgs, R., Deckers, S., Van Neer, W., Smets, E., Govers, G., Verstraeten, G., Steegen, A., and Cauwenberghs, K.: Man and environment in the territory of Sagalassos, a classical city in SW Turkey, Quaternary Sci. Rev. 18, 697-709, 1999.

Waelkens, M., Sintubin, M., Muchez, P., and Paulissen, E.: Archaeological, geomorphological and geological evidences for a major earthquake at Sagalassos (SW Turkey) around the middle of the 7th century AD, in: The Archaeology of Geological Catastrophes. Geological Society London, London, 373-383, 2000.

Waelkens, M., Vanhaverbeke, H., Martens, F., Talloen, P., Poblome, J., Uytterhoeven, I., Kellens, N., Putzeys, T., Degryse, P., Van Thuyne, T., and Van Neer, W.: The Late Antique to Early Byzantine city in Southwest Anatolia. Sagalassos and its Territory: A case study, in: Die Stadt in der Spätantike - Niedergang oder Wandel? Akten des Internationalen Kolloquiums in München am 30. und 31. Mai 2003, Stuttgart, 199-255, 2006.

Wick, L., Lemcke, G., and Sturm, M.: Evidence of Late glacial and Holocene climatic change and human impact in eastern Anatolia: high-resolution pollen, charcoal, isotopic and geochemical records from the laminated sediments of Lake Van, Turkey, Holocene, 13,665-675, 2003.

Walter, H.: Die Vegetation der Erde, Bd. 2 Die gem/issigten und arktischen Zonen. G. Fischer, Jena, 1968.

Zohary, M.: Pflanzen der Bibel, 3rd Edn., Calwer Verlag, Stuttgart, 1995. 